\title{
Theorizing refugeedom: becoming young political subjects in Beirut
}

\author{
Liliana Riga ${ }^{1}$ (1) $\cdot$ Johannes Langer ${ }^{1}$ (D) $\cdot$ Arek Dakessian $^{2}$
}

Published online: 5 May 2020

(C) The Author(s) 2020

\begin{abstract}
Refugees can be formed as "subjects" as they navigate forced displacement in countries that are not their own. In particular, everyday life as the politicized Other, and as humanitarianism's depoliticized beneficiary, can constitute them as political subjects. Understanding these produced subjects and subjectivities leads us to conceive of forced displacement - or "refugeedom" - as a human condition or experience of political (sub)alterity, within which inhere distinctive subjectivations and subjectivities. Drawing on fieldwork in Beirut, Lebanon, we use young Syrian and Iraqi refugees' experiences with everyday racism, violent bullying and racialized discrimination as heuristic lenses with which to see displacement's political subjects and subjectivities. We argue that the young refugees emerge as both political and moral subjects through core and defining struggles within - and against - these politicizing constraints. We interpret their struggles as ambivalently and dynamically situated within humanitarianism's and racism's subjections and subjectivities. Yet we also found that occasionally the young refugees could eclipse these produced subjectivities to claim repoliticized subjecthoods distinct from those of humanitarianism and outside displacement's normal politics. We interpret these in Rancièrian terms as "political subjectivation." Abstracting our findings, we offer a simple theoretical architecture of refugeedom's subjectivations, subjects, and subjectivities as comprising humanitarianism's rights-bearing or juridical subject; the vulnerable and resilient, innocent and suffering subject; and the Othered or racialized subject, formed through the exclusions of displacement's politicized spaces. But we also conceive refugeedom as a space of values, and so the ground on which moral meaning and significance attach to agency and subjectivity.
\end{abstract}

Liliana Riga

1.riga@ed.ac.uk

Johannes Langer

j.langer@sms.ed.ac.uk

Arek Dakessian

ADakessian@qmu.ac.uk

Extended author information available on the last page of the article 
Keywords Forced displacement $\cdot$ Jacques Rancière $\cdot$ Political and moral agency $\cdot$ Racism and racialization $\cdot$ Refugees $\cdot$ Subjectivation and subjectivity

"I'm 17 years old. I'll be 18 in a month ... I very much dislike discriminating against or being discriminated against ... Once I went to work at a salon. It's like they were holding me accountable for being Syrian. I used to make 150,000 LL and the other girl used to make 250,000 LL. She'd always leave early and I'd always still be there when she left ... 'Why does she get paid more than me?' He said, 'because she's Lebanese ... you know that you can't speak Syrian at this salon if you want to keep working here.' I called another salon to learn how to wrap hijabs. As soon as I told her I'm Syrian she told me she has no work for me there. I then called her from another number, I told her I'm Lebanese. I even changed what I am. She said you're welcome here. Come anytime you want ... I used to lie to people and tell them I'm not Syrian. Nor would I tell them I'm a Muslim. Because complexes are in their blood. And backwardness is in their blood. And, always, because Syrians make trouble, I bear the consequences with everyone ... Because the group, no matter what they did, we have to bear the responsibility for it, if we were good, if we were bad. Will there come the day in which I live a free woman?"

In this poignantly observed telling of her first experiences of making her own way in Beirut, a Syrian refugee allows us to see both the ordinariness of everyday racism and what navigating it demands. As she makes sense of her experiences, she gives meaning to the racializations by situating them within the wider political struggles and ethical commitments in which she finds herself. Everyday and intimate encounters in schools, camps, neighborhood streets, workplaces and humanitarian spaces index her social world. Put more formally, these are also the grounds on which forced displacement politicizes subjects and allows for the agential constitution of subjectivities. This paper explores these racializations and seeks to theorize what they tell us about the lived experience of forced displacement.

Our conceptual framing takes as point of departure the observation that to be forcibly displaced in a country that is not one's own is also to be structurally situated in a relationship of political (sub)alterity and constraint. Positioning forced displacement as in this way inextricable from the political is to reconceptualize its subjectivities as bearing greater resemblance to those of the postcolonial subaltern than to those theorized as inhering in a depoliticized "bare life." This recognition invites us to move away from seeing displacement as a descriptive category or process, toward conceiving it in a more explicitly political and analytical frame - "refugeedom." Our objective is to find an interpretive route for retheorizing forced displacement as a human condition and experience of political alterity, within which inhere distinctive subjectivations, subjects and subjectivities. Thus, we put the framing questions like this: What does it mean to live one's life structurally situated in a relationship of political (sub)alterity and constraint? What might the constitution of political subjecthoods within these 
conditions and experiences look and feel like? And how might these inform a theorization of refugeedom as a distinctive human condition of political alterity?

We empirically explore these possibilities in research with young Syrian and Iraqi refugees in Beirut, Lebanon. Part of the political of refugeedom, of course, involves living the "humanitarian condition," which we conceptualize as navigating the everyday fundamentals of getting on with life when displacement perdures (Feldman 2018; cf. Allan 2013). Children and young refugees, in particular, can become dependent subjects of refugee humanitarianism's depoliticized constructions of trauma or victimhood, and of its figurations of the vulnerable and resilient young person (Fassin 2012, Ch. 8; Malkki 1995, Ch.3). But young refugees are also not spared the subjections of the wider political as they navigate everyday lives as racialized Others. Indeed, we contend that experienced racism in displacement most especially implicates political subjectivities. This is because it unavoidably entangles the structural realities of being both a politicized Other in a country that is not one's own and a depoliticized subject of humanitarianism. We use the young refugees' accounts of their everyday experiences with (violent) racializations and discriminations as heuristic sociological lenses with which to see displacement's political subjects and subjectivities. Drawing on an expanded theorization of the political in relation to their ordinary and intimate lives, then, we theorize their navigations of refugeedom's entangled subjectivations in the first instance in classically Foucauldian terms. They are ambivalently and dynamically situated between subjection and subjectivity (Butler 1997; Foucault 1982). Yet as we move through our data, we go a little beyond these classic theorizations of subjectivation and interpret some of the young refugees' constituted subjecthoods as effectively opening what Jacques Rancière (2004, p. 304) uniquely posits as "an interval for political subjectivization."

Our account is based on a series of informal focus groups with 24 camp- and urban-based 11- to 16-year old refugees under the care of three humanitarian organizations in Beirut, a politically rich and complex city with one of the highest per capita displaced populations in the world. We describe how the young Syrians and Iraqis think and feel their ways through its humanitarian spaces, in and around the city's Mar Elias Palestinian Camp, and in the neighborhood schools and streets of Mouseitbeh, Mazraa and Sed el-Bouchrieh. Following a discussion of critical humanitarianism's theorizations of the depoliticized refugee subject, we outline our data and methods. We then position Beirut and its complex migrant and sectarian contestations as materially constitutive of the young Syrians' and Iraqis' navigations and subjecthoods. Next, we present their accounts in five steps, each building on the previous one, and each analytically framed by the young refugees' own formulations: "What kind of question is that!?"; "All the stuff they say about us"; "If you're walking alone, you're gonna eat it." ... "Without salt!"; "Sometimes we act, but with caution"; and "In my heart, there's something like a fire - it burns." Our interpretation of their navigations concludes by proposing a theorization of refugeedom which contains a deeper repoliticization of "the refugee subject." 


\section{Retrieving political and moral subjects}

As point of departure we take two related theorizations of the depoliticized "refugee subject." The first argues that humanitarianism's practices can depoliticize the forcibly displaced by forming them into suffering subjects. Fassin (2012, p. 21) writes that humanitarianism's emphasis on victimhood, trauma and bearing witness can mean that "the social origins of suffering and distress, including poverty and discrimination, even if fleetingly recognized, are set aside." One consequence is the production of "a form of subjectivity devoid of historical [and political] subject" (Fassin 2012, p. 222; see also Fassin and Rechtman 2009; Malkki 1996). Yet this depoliticization might equally be the product of humanitarianism's sunnier side, which repositions the traumatized refugee as psychologically resilient and socio-culturally resourceful. Vulnerability and resiliency are dimensions of the same suffering subject, in other words. Both are formed through similar universalizing commitments to neutrality within humanitarian regimes of care (cf. Barnett 2011, Ch. 10; Bornstein and Redfield eds. 2010; Feldman and Ticktin eds. 2010; Ticktin 2011). And indeed, one of the core struggles of the forcibly displaced lies in challenging elements of both of these constructions (cf. Agier 2002, 2011; Malkki 1995; Pupuvac 2008; Rajaram 2002; Zetter 2007). In this regard, refugee children are often considered the paradigmatic suffering subject. As innocent and pure recipients of care and compassion, they become figurations possessed of legal entitlements, vulnerabilities, and resiliencies, and so they - and their childhoods - are to be sheltered from politics (cf. Elshtain 1996; Malkki 2015, Ch. 3; Marshall 2013, 2014). Moreover, when informed by these policy framings (for example, UNHCR 2017), our theorizations can attune to similarly aligned understandings of forced displacement (cf. Bakewell 2008; Boyden 2003; Chatty 2010b; Fernando and Ferrari eds. 2013; Hart 2014; Hart ed. 2008; Hutchinson and Dorsett 2012; Kihato and Landau 2017). It is possible, however, that in this analytical weakening of the political we might be mis-specifying as context those experiences that give displacement and its subjectivities their distinctive shapes.

Put differently, this first theorization of the depoliticized subject holds that in diminishing the refugee's experiences of political alterity, we push much of the stuff of everyday existence off-frame because we also obscure its basic relationalities. This is especially the case when young refugees experience their everyday lives as hyperpoliticized or dangerous security threats, governable subjects, radically racialized Others, or adultified targets of state brutality (cf. Chatty 2010b; Kovner and Shalhoub-Kevorkian 2018; Marshall 2013, pp. 54-55; 2014, pp. 282, 293; NguyenGillham et al. 2008; Peteet 1994). Illustrative is Fassin's (2012, pp. 201-214) example of Médecins Sans Frontières' (MSF) work with Palestinian boys, seen as stonethrowers by day and found by MSF psychologists to be bedwetters at night. Despite deeply politicized and racialized daily lives, their anxieties, nightmares and bedwetting were abstracted as normal expressions of the repressed fears to which they were subjected and bore witness. A psychologist cited by Fassin (2012, p. 211) explained: "in front of the soldiers, in front of their friends, and even within their family, they have to present themselves as strong, almost adults. Wetting the bed is their way of showing that they are still children." So instead of the martyrs or political actors they claim themselves to be, the subjugations of military occupation are studiously set aside to care for them as fragile and traumatized children. And here perhaps an even further 
"subjectivation of the political" takes place: the exchange of "the political martyr with a neurotic subject, substituting the politics of justice proclaimed by the martyr with the politics of compassion, which has the sufferer as its object" (Fassin 2012, p. 211).

This substitution also crucially masks experienced political injustice and leads us to a second related theorization of the depoliticized subject. Here the refugee is not a depoliticized suffering subject, but a depoliticized rights-bearing subject. Agamben (2008, pp. 92-94) frames its core tension:

the figure that should have embodied human rights more than any other - namely, the refugee - marked instead the radical crisis of the concept ... [B]y breaking the identity between the human and the citizen and that between nativity and nationality, [the refugee] brings the originary fiction of sovereignty to crisis.

Stripped thereby of substantive rights and values, the formation of the refugee subject through biopolitics and its states of exception is a form of sovereign domination. It reduces to "bare life" those who should be quintessential political subjects entitled to human rights. It relegates them to "zones of abandonment," zones which, themselves fragile, have limited resources for humanely sustaining the forcibly displaced (Agamben 1998, 1995; Biehl 2005). In this way the rights-bearing refugee has her rights emptied of their meaning. And as rights are hollowed out, the political has also been quietly evacuated, in due course depoliticizing the subjectivities that emerge in its train. Still, this view perhaps leaves little room for seeing the practical ways in which the displaced can and do assert themselves as political actors - not least by claiming their human rights.

This empirical critique of "bare life" comes into clearer view in light of those political subjectivities that lie behind emic narratives of violence and suffering that contest humanitarianism (Sigona 2014); in lip-sewing protests against humanitarianism's sometimes inhumane treatment (Owens 2009); in "becoming subjects" while claiming back a sense of "temporal justice" (Fontanari 2019); in appropriating the refugee category as "a vital, positive dimension of their collective identity in exile" (Malkki 1996, p. 377); in resisting humanitarianism's imposition of secularism and women's empowerment when these paradoxically silence violence and perpetuate inequalities (Fiddian-Qasmiyeh 2014); and in confronting humanitarian aid's "compassionate authoritarianism," even while appropriating its produced subjectivities for specific political ends (Holzer 2015). Forced displacement is thus seen not as a zone of abandonment, but as a landscape for constructing sites for politics; and its architects are not "humans in waiting" (Marshall 2013 , p. 63), but political agents crafting rich public lives in cities and camps as they build political and moral communities (cf. Agier 2002, 2011; Chatty 2010a; Grbac 2013; Martin 2015; Sigona 2015). Thus, Feldman (2018, p. 24) writes that they are "persistently engaged in efforts to alter their world and that even as humanitarianism poses barriers to such efforts, it also creates political opportunities."

Refugees do politics in this rights-based, transactional sense every day, of course. Yet if forced displacement's lived political dimensions are not as reductive as rightless "bare life" implies, neither are its constituted subjectivities. This is to suggest that even if rights can be substantively emptied, the political and its possibilities need not be. To better see the agential constitution of political subjects and subjectivities while still retaining displacement's subjugations, we might ask, with Butler (1997, pp. 29-30): "is there a way to affirm complicity as the basis of political agency, yet insist that political 
agency may do more than reiterate the conditions of subordination?" Mindful of the complexities of theorizing political agency and subjectivation, we draw on their entanglements. Most fundamentally, subjection binds the individual to "his [sic] own identity, imposes a law of truth on him which he must recognize and which others have to recognize in him" (Foucault 1982, p. 781). It is subordination; but it is also the possibility of the agential emergence of "becoming a subject" together with its constituted subjectivities (Butler 1997, p. 14; Foucault 1982, p. 785). This process is bound up with political agency, so there is recognition of "an ambivalence at the site where the subject emerges"; through its "continuing condition of possibility," agency is itself an effect of its own subordination because "the subject cannot quell the ambivalence by which it is constituted," and, indeed, by the very "reiterated ambivalence at the heart of agency" (Butler 1997, pp. 4-12, 17-18).

We embed the essential element of this classic theorization of subject formation within a more expansive Rancièrian understanding of political subjectivation. The aim is to find an alternative route for theorizing and expanding the range of possibilities that constitute forced displacement's political subjects and subjectivities. Challenging those theorizations grounded in humanitarianism, "bare life" and human rights, Rancière (2004, p. 304) writes: "the very difference between man and citizen is not a sign of disjunction proving that the rights are either void or tautological. It is the opening of an interval for political subjectivization." This is because politics is not a fight over rights between a subordinating power and a subjected subaltern; it is instead "a matter of subjects or, rather, modes of subjectification" (Rancière 1999, p. 35). That is to say, the political struggle for rights and recognition does not take place on the terrain of normal politics or even within humanitarian space. If it did, it would simply reproduce the existing political field or "normal state of things," an as yet unimagined political space would be a priori foreclosed, and so too would the potential for new subjective space and subject formation (Rancière 2016, p. 51; 1999, pp. 35-36). In this consensual depoliticization, rights "become the rights of those who have no rights, the rights of bare human beings subjected to inhuman repression and inhuman conditions of existence," Rancière (2004, p. 307) argues, "they become humanitarian rights, the rights of those who cannot enact them, the victims of the absolute denial of right." This kind of claiming reiterates rather than challenges one's identification and assigned place in the body social (Rancière 1999, pp. 126-127, 136-137). It is a wrung or distorted form of political agency because it is based on identification with the inequalities that govern the established "distribution of the sensible." It is, in short, political agency that becomes "identification" (Rancière 1999, pp. 37; 2004, p. 306) that becomes "governmental subjectivization" in Foucauldian terms.

By contrast, political subjectivation in a Rancièrian sense entails something rather different. It is the struggle or claim to existence of a political subject that takes place when those who are politically inaudible and invisible in the social order contend and verify an essential egalitarianism (Rancière 1992, p. 60; 1999, p. 17). This claim to political subjecthood "is never the simple assertion of an identity," but the refusal or "denial of an identity given by an other, given by the ruling order of policy" (Rancière 1992, p. 62). It is a dis-identification, or an "opening up of a subject space where anyone can be counted" (Rancière 1999, p. 36). Political subjects form or emerge in the interval or gap between, on the one hand, those identities or ascriptions given to them by the social order, and on the other, the potential self that is equal in the abstract but 
that does not yet exist in reality. They do this by placing subjective commitments in between these identities. The Rancièrian political subject is not contained within or delimited by humanitarian rights or citizenship categories, for instance. So political subjects emerge not from positions of victimhood, but in the act of naming an originary wrong, that is, in the act of opening up a political space of potentiality by the "unaccounted" in verifying or demonstrating their radical equality (Rancière 2016, p. 43; 1992, p. 60). ${ }^{1}$ Thus, as political subjects make claims not to those humanitarian rights to which they would otherwise be entitled, but rather in the name of deeper, axiomatic rights that inhere in the wider political, they "put together the world where those rights are valid and the world where they are not. They put together a relation of inclusion and a relation of exclusion" (Rancière 2004, p. 304).

This way of redimensionalizing "the political subject" might offer more dynamic ground for theorizing - and repoliticizing - both "the refugee subject" and forced displacement. If we understand the refugee "self" as being held in subjectivation's ambiguous tension of continual becoming, entangled between self-shaped subjectivities and the processes and structures of displacement's subjections (Oberprantacher and Siclodi eds. 2016, Part IV), then the political landscape of forced displacement might be seen in more analytically Rancièrian terms as a "conflict over the existence of a common stage and over the existence and status of those present on it" (Rancière 1999, pp. 26-27). This repositioned subjectivity is equally suggestive for thinking about what we mean by political agency within refugeedom as we conceive it. In Charles Taylor's (1989, p. 33 and passim) beautifully argued analysis, agency is about what "self" is possible within existing conditions of, or orientations to, moral values; it is not an abstract or absolute freedom from these constraining conditions or wider value orientations. As Biehl et al. (2007, pp. 5, 15) suggest, if the "inner lives of subjects" exist within wider moral conditions, we might then see subjectivity as a "strategy of existence," because it tells us how people "forge and foreclose their lives around what is most at stake" in their "making and unmaking of meaning." To have agency within the political, in other words, is also in the deepest sense to have moral agency (Taylor 1989, Part I). This is to position subjectivities as intertwined with the values that inhere in particular human conditions, settings or contexts; it is to position subjects and subjecthoods as constituted by both political and moral agency; and it is to position refugeedom not only as a space of political alterity, but also as one of particular values and sensibilities.

In this way, the political and other subjectivations that we understand as inhering in forced displacement shape the young refugee's everyday lives and allow us to also think about refugeedom's moral dimensions. The data we offer speaks empirically to varying relationships of subjugation, and to the ways in which these relationships both manufacture and make possible their emergent political and moral subjectivities. We will see the formation of the young Syrian and Iraqi refugees as humanitarianism's depoliticized suffering subjects, as well as its similarly depoliticized rights-bearing subjects. We will also see how they become structurally politicized and racialized

\footnotetext{
${ }^{1}$ For Rancière (2016, pp. 47, 64-65 76; 1999, p. 89), political subjects in a strict sense emerge not as individuals or identifiable groups, but as an abstract egalitarian community that comes into being through political claims-making. We interpret this construction more loosely simply to capture what we take to be the essence of Rancièrian political subjectivation.
} 
Others in their adopted city. They are part of communities that find themselves at the sharp end of social dilemmas, fears of otherness, and constrained choices for allocating scarce resources. But as selves are constructed through these everyday politics and moralities, and as the young Syrians and Iraqis make their ways through the circumstances and workings of their social worlds, we will also see hints of something else. Instead of "creating new figures of the Inhuman" (Rancière 2004, p. 297), that is, instead of reiterating existing refugee subjecthoods, very occasionally, their subjective commitments hinted at deeper moral and political reimaginings of "the refugee subject," and even of forced displacement itself. Thus, what might we see if we set aside our sociological categories of racism, and opened space for the young refugee to define the meanings and workings of her social world in her own subjective register? What might it look like to position political and moral subjects and subjectivities as the objects - and not the context - of our analyses? And how might they speak of forced displacement not as category or state of being, but as a politicized human condition?

\section{Methods, terms, choices}

In what follows, we work to present vignettes or fragments of the young refugees' ordinary navigations of their streets, camps, schools and humanitarian spaces. Our theorization is based on the last phase of a large two-year research project undertaken by a team of seven researchers (Riga et al. forthcoming). Our account draws on informally constituted focus groups with 24 young refugees, 12 Syrian and 12 Iraqi, all under the care of three Beirut-based humanitarian organizations. We chose these organizations for their work with displaced youth. One was small and locally based, and two were larger with international funding, so they each provided services of varying reach. The focus groups had between three and nine participants, comprised of either Syrian or Iraqi (Chaldean Christian) refugees, but never both together. All were conducted in Arabic and a native speaker in our team simultaneously translated discussions, with participants themselves occasionally contributing to the translations. Participants were simply those young beneficiaries under the care of these organizations, so anyone who wanted to participate was welcome and no other criteria were applied. Half the refugees were girls and half were boys, with the majority between 11 and 16 years old. Most had been in Lebanon several years; all were urban or campbased; and nearly all received schooling. We do not claim this as a representative sample of displaced youth in Lebanon. However, our participants share with approximately one-half of refugee children in Lebanon the fact that they are in schooling, and the reality that they live in poor urban or semi-urban areas or in the Palestinian camps vulnerable spaces that today host the largest communities of displaced Syrians (UN 2019, esp. pp. 14, 15, 57, 171, 180).

Over the course of one and a half years of fieldwork we met social workers, clinical psychologists, field workers, managers and counsellors at the three partner organizations. In addition to the focus groups, therefore, we also draw on targeted interviews with eight social workers, psychologists or aid workers at two humanitarian organizations, and observational data, informal conversations and engagements with staff and refugees at all three organizations. In our use of video diaries during an earlier stage of fieldwork, we noticed that racialized bullying and discrimination were significant and 
routine features of their everyday lives and relationship navigations. In fact, the quote we used to open this article comes from one of these video diaries. On this basis, then, we began focus groups with an open question: "do you ever experience bullying? What is it like?" We soon understood that the distinctive ways in which they constructed their accounts were expressive of deeply politicized subjects and subjectivities. Their experiences with racism, racialization and discrimination became in this way heuristic lenses with which to see how political subjectivities can come to be constituted, understood and articulated. Mindful of racialization's contested definitions and of its usefulness (cf. Miles and Brown 2003; Murji and Solomos eds. 2005; Omi and Winant 2015) we understand it in the tradition of approaches that entwine - rather than juxtapose - "race" and culture (Appiah 1985, 1996; Brubaker 2009). We conceive racialization as an embodied power relationship and subjugating process that attaches meaning, significance or negative value to physical or cultural difference (cf. Fassin 2011; GonzalezSobrino and Goss 2019; Song 2014). And here we deploy it more specifically as generative of racial subjects, understood as both subjection and subjectivation.

We recognize that children are defined as those to age 18 by the UNCRC (Article 1), but that older children often prefer to be referred to as youth or young people. However, we use the terms "young refugees" and "young Syrians and Iraqis" rather than either "children" or "young people" for two reasons. First, we are in line with current thinking in the sociology and anthropology of childhood, which draws attention to children's status as social agents and as active members of society (James and Prout 1997; Wyness 2015, Ch. 1-2). There is increasing recognition that children are political, historical and social agents, not least as they live through significant political events and epochs (Boyden and de Berry 2004; Chatty et al. 2005 and Wyness 2015, Chs. 12). Thus, the use of "young" sociologically signals the way in which "agency is conceptualized as a social, moral and embodied aspect of children's lives," and this against the older view of children's "agency as a relatively adult-free sphere of autonomy" (Wyness 2015: 33). Second, we use the term "young refugees" or "young Syrians and Iraqis" and not "young people" because we position them intersectionally as young, as refugee, and as Syrian or Iraqi - constructions and realities that are not additive but that produce instead a unique form of politicized experience. We seek thereby to move away from depoliticized and universalist approaches and draw attention instead to "the contingency and historicity of the processes" through which they are in "dynamic relationship to their immediate social environment" (Hart 2004, pp. 168, 172). In short, we assume, with Hart (2014, pp. 386, 387), that the young Syrian and Iraqi refugees are "agentive beings negotiating the conditions of their existence," and that they may "may act in meaningful ways upon their situation," which is the lived experience of refugeedom as we understand it.

And finally, while we are concerned with retrieving political subjectivities and recognize that the research practice of anonymity can erase or render these invisible (Moore 2012), the precarious contingencies of displacement make de-anonymization too high a risk. Due also to the intimate nature of humanitarian care circles in Beirut, even the use of first names might make the young Syrians and Iraqis identifiable to those in and close to these circles. We therefore chose to use the first initial of the participant's name followed by an " $\mathrm{f}$ " for females and an " $\mathrm{m}$ " for males, with occasional qualifiers in the middle to distinguish participants. We recognize that these are awkward to read, but we want the young refugees to retain sufficient specificity so 
as to be able to identify themselves, while still protecting their identities from other readers. Accordingly, we also anonymize the humanitarian organizations.

\section{Beirut}

Some of the young Syrians and Iraqis live in and around the Palestinian camps Dbayeh, Shatila, Burj el-Barajneh and Mar Elias. Others live among Beirut's poor and disenfranchised on the city's edges, in the neighborhoods of Mouseitbeh, Mazraa and Sed el-Bouchrieh. The sectarian and migrant contestations that define these spaces profoundly shape everyday encounters. These are the substance and material of subjectivities, the stuff of the "orchestration of the self" (Biehl et al. 2007, pp. 1415). Here, experienced racism - embodied and relational - often finds violent expression in schools, streets, and football fields, for instance. In these encounters we see the constitution of political subjects who think and feel through racialized relationships and spaces and who negotiate Beirut's moral geographies - or the ways in which "certain people, things and practices belong in certain spaces, places and landscapes and not in others" (Cresswell 2005, p. 128). The young Syrians and Iraqis seem to perfectly understand the rules that govern their everyday spaces of displacement; they also understand how their intimate social worlds draw into them all of Beirut, the whole of Lebanon, and indeed the complicated contentions of the wider Middle East.

In meaningful ways, then, the young refugees emerge as Beirutis - if perhaps never Lebanese - as the city's complexities shape the reach of their political and moral agency. These complexities come into view, for instance, in the relationship between the city's long-term residents and its more recent guests. Lebanon is neither a signatory of the Refugee Convention nor officially recognized as a country of asylum - and both for fear of tipping delicate sectarian balances (for discussion cf. Janmyr and Mourad 2018, esp. p. 8; Janmyr 2016). Yet state, local municipalities, and ordinary Lebanese have shown remarkable hospitality towards the arrival of the newly displaced, not least in generously providing educational opportunities by mandating that schools operate two shifts to accommodate Syrian and Iraqi refugee students (Buckner et al. 2018, p. 542; MEHE 2016). The Lebanese have also demonstrated warmth, sympathy and understanding towards Syrians by opening their homes and sharing their resources (Christopherson and Thorleifsson 2013, p. 3; though this has varied over time, cf. Thorleifsson 2016; Chaaban et al. 2016, p. 6; Alsharabati and Nammour 2017). And all of this in light of the remarkable fact that Lebanon globally hosts the largest per capita number of refugees (UN 2019, p. 5). There is, in short, the very real possibility of belonging in a city whose rich complexities both welcome and racialize.

These racializations are structurally evident in Beirut's sectarian geographies. Despite their confessionally mixed residents, the city's neighborhoods remain seats of electoral political power: Muslim votes belong in the West, Christian votes the East; Sunnis in Qoraitem, Shiites in Dahiyeh; Maronites in Achrafieh and Armenians in Bourj Hammoud, for instance. Beirut's cosmopolitanisms - downtown's gated corporatism, Hamra's secular Arabism and Achrafieh's high-brow francophonism - similarly spatialize the legacies of a 15-year civil war, whose narrative vacuum has been filled by community solidarities "forged in part around a construction of the sectarian other as enemy” (Seidman 2012, pp. 5, 29; cf. Makdisi 2006). Refugees and migrants live at the 
geographic and moral seams of these spaces and their historical solidarities. Palestinians are sequestered in their camps; Syrians and Iraqis at the city's edges with Beirut's poor, or more recently in the Palestinian camps; migrant Hindu and Buddhist domestic workers are invisible inside private middle-class homes, where women from the Philippines are at the top of Beirut's low-status class hierarchies, while Sri Lankan domestic workers continue to remain at the bottom (cf. Beck 2018; Jureidini 2002; Jureidini and Moukarbel 2004, pp. 586, 590).

Historically, migration's mobilities and their resultant integrations have been easier for Christians than Muslims across the Middle East (see Chatty 2010a, pp. 134-179), and Lebanon is not an exception. If Syrians and Iraqis are foreigners, they are also Sunni, Shiite and Christian Arabs whose presence has the potential to threaten hardwon yet fragile sectarian balances. Iraqi and Syrian refugees occupy different - though similarly liminal - places in Lebanon's moral geographies of migration and refugeedom. And we see some of the nuances of these differences reflected in the young refugees' accounts because the Iraqis in our focus groups were Christian Chaldeans. Syrians most especially have historically borne witness to Lebanon's internal contestations, having provided - alongside Egyptian migrant workers - the inexpensive manual labor that maintained Beirut's pre-war infrastructure and that led its post-war reconstruction (Chalcraft 2009). Already viewed by Lebanese as their backward Arab cousins, their presence in Beirut has become increasingly politicized - in the early 2000s as metonyms for Damascus in a city that was looking to kick Damascus out, and more recently as "dirty" refugees. One effect of these worries is that Lebanon maintains a no-camp policy to protect its political fragilities, relying instead on shortterm, ad hoc settlement. Yet in the absence of formal camps, Syrian refugees have sought shelter wherever they could in informal arrangements and settlements (Janmyr 2016; UNHCR\UNICEF\WFP 2017, p. 22). By contrast, the Iraqis' more welcoming accommodation has followed Beirut's sectarian geographies, with Christians settling in the northern and eastern suburbs and Muslims in the suburbs to the south and west (Chatty and Mansour 2011, p. 74).

These fluid cosmopolitanisms and diversities can also mask Beirut's more rigid, underlying moral geographies. Similar and perhaps even more finely calibrated hierarchies of diversity define Beirut's Palestinian camps, where some of the young Syrians live, and where the Syrian displacement from 2011 is yet another of the many upheavals that have reshaped camp life. For decades, both the camps and the humanitarian structures that administer them have been contested sites of politics, with fractured lines of authority and competing sect and class projects of statehood (Salibi 2003, pp. 183199; Traboulsi 2012, pp. 147-149, 152-155, 156-183). As a result, they are complex and politicized spaces where political power is diffuse and contested (Hanafi and Long 2010); they are equally complex social spaces in which the confluences of urbanization, migration, refugeedom and poverty combine to create particular moral geographies; and they are semi-bounded spaces of confinement, whose borders are nevertheless porous with those of the city and its surrounding poorer areas (Doraï 2010; Martin 2015).

As the arrival of Syrian refugees and displaced Palestinians from Syria remake Beirut's neighborhoods, then so too their presence in the Palestinian camps challenges existing political fragilities and humanitarian realities, now in their third generation of displacement (Allan 2013; Chaaban et al. 2016, p. 6; Feldman 2017, 2018). In Shatila, for example, established Palestinians initially drew on whatever formal and informal 
resources and networks they had to assist the early arriving Syrians (Fiddian-Qasmiyeh 2016). But given the Palestinians' differing legal statuses under UNRWA and given the claims of newly displaced Palestinians from Syria, new tensions emerged, and older ones have been awakened (Sharif 2018). Palestinians seek to protect their camps and surrounding spaces to preserve whatever political autonomy they have. As a result, Ramadan (2013, pp. 70, 72, emphases original) argues, Beirut's camps still retain "specifically Palestinian values, identities and practices," and become "spaces of sovereign abandonment filled with an alternative order (sometimes disorder) that can have the capacity to produce its own political life" (cf. also Hanafi and Long 2010).

\section{Navigations}

Lebanese hosts and refugee communities live together in these complex, politicized and contested city spaces, which can define and subjectify, but which they themselves can struggle to shape. The young Syrians and Iraqis also experience the city's sometimes arthritic political structures through its humanitarian spaces - a vibrant, post-civil war humanitarian landscape that has among the highest NGO-to-citizen ratios in the Middle East (AbouAssi 2012, p. 587). We present their accounts of these navigations in five cumulative steps. We first show how young Syrians and Iraqis interpret their experiences with racialization and discrimination as part of their normal, everyday realities in Beirut. Second, in analyzing the form and content of these racializations, we see how young refugees become political subjects and how their own claimed political subjecthoods are constituted. We next consider how they respond to these racializations and their produced subjectivities, both through cultural intimacies and as political and moral agents. And finally, we show what resistance to feelings of injustice in conditions of structural and political powerlessness can look like to them.

\section{"What kind of question is that!?"}

"There's a lot! Loads, loads!" "The whole [Palestinian] camp makes us hear [that we are Syrian]!" The young refugees made little attempt to hide their surprise when asked if they experienced bullying. "What kind of question is that?!" a Syrian boy whispered to his friend, astonished we had missed the memo that the sky was blue. "We go through this every day!" Tf said, "they just treat us badly." Young refugees understand racialized bullying as a routine part of their lives, normalized in the landscape of the everyday to the point of ordinariness. And yet despite - or perhaps because of - its ubiquity, the ordinary has necessarily faded into the background and become the unremarkable. "We've been through this so many times we're cold to it now. It's fine," Jm told us. We understood that it takes a lot of work to sustain the intensity of anger at injustice. One aid practitioner with one of our partner organizations interpreted these experiences as simply part of the more generic realities of bullying that happen to all children. In fact, daily and routinized racism was understood in this way by nearly everyone - young refugees, parents, teachers and humanitarian care practitioners alike.

Yet the politicizing effects of these racializations become evident in the separation of public-school classes, for instance, which comprise morning shifts for Lebanese students and afternoon or second shifts for refugees. Designed by the Lebanese Ministry 
of Education and Higher Education (MEHE) in response to the challenges of providing equal access to education to all children, they pose a significant infrastructural challenge. Bus drivers drop off second shift (refugee) students at the schools before picking up first shift (Lebanese) students to drive them home. This means that refugee students must wait outside the school until all the Lebanese students have left, which often leads to tensions in the changeovers. In the transition between shifts, and again following the afternoon shift, they are especially vulnerable to (violent) racialized bullying because they are easily recognizable and so cannot avoid confrontations. "They didn't know I was Syrian in my school," AHm said, "but I told them, in the end, because I go in one way and they leave the other." The shift practices have thus gained social and racialized significance. A social worker at another partner organization told us that even where both shifts are desegregated, "the children now ask each other, 'am or pm'?"

Teachers and the MEHE view this segregated education as an expedient, equitable, and reasonable - albeit imperfect - response to the education crisis (Shuayb et al. 2014, p. 103). Yet tensions find their ways into classrooms, particularly acutely for Syrian refugees and Palestinian refugees from Syria, as shift practices institutionalize racializing and subjecting markers that define them as second-class students. These politicized demarcations fluidly move between school and street and back again in ways that have not gone unnoticed, however. Local and international policy analysts, the MEHE, the United Nations Relief and Work Agency (UNRWA), and academic studies have consistently noted the ubiquity and magnitude of everyday racialized bullying and violence, not only around school practices, but also in surrounding neighborhoods and camps (cf. MEHE 2016, p. 9; Shuayb et al. 2014, pp. 64-67, 111). As tensions between communities find expression in classrooms and between children, there is wide consensus on the substance and scale of the problem, acknowledged by MEHE (2016, quote p. 15, see also pp. 9, 10, 17-18) as "the need to address issues such as bullying, violence and discrimination."

Still, the wider narrative is that the more pressing and urgent realities of everyday life in forced displacement demand that the role of everyday racism be redimensionalized, or revalorized, as lower priority. Two psychologists, the first affiliated with a large, international NGO (not our partner), and the second working for one of our partners, offered very similar explanations:

What would you be more worried about? The fact that you're not sure whether you're going to have dinner tonight or that the other kids in the neighborhood don't like you? They have much bigger problems than this, and we have much more urgent matters to provide for than this. Hygiene, domestic abuse, malnutrition...

When we reach the point where the child talks about bullying, it's usually after having spent lots of time talking about things that are happening at home first, then we come to the other topic. ... The poverty that Syrian people are living in Lebanon is not acceptable ... So, children usually talk about these things before talking about the bullying, because they're not able to eat, they're not going to school, they're not dressed properly ... These things affect Syrian kids more than the bullying. Yet the bullying is the cherry on the top, it's not that easy. 
Despite this consensus, however, a recent UNHCR-funded survey showed that physical security (broadly understood but including fear of assault) ranked among the Syrians polled as a greater worry than health, education, rent, work or inflation (Alsharabati and Nammour 2017, p. 17). It was therefore easy to see why the young refugees' families were more anguished, if ambivalent, about the impact of routine and daily experiences of racialized bullying on their children.

The mother of a Syrian boy in one focus group - whose family experiences the Palestinian Mar Elias camp's even sharper racializations - pulled our researchers aside and confided:

I don't want what my son does with you to be seen by anybody else. He might well talk about the discrimination we face, and if word gets out then we will be kicked out of the camp as ungrateful guests. I'm happy for him to participate because it really affects him, and it would be good for him to talk about it, but what he says cannot get out.

The young refugees understood and recognized their families' need to revalorize experienced racism. "I don't say anything to my brother, because if my brother sees me get hit, he's going to make a big fight," AHm said. M1m agreed: "we can't speak to the parents about this." Unlike their families and caregivers, though, they did not see racialized bullying as the least of their problems, quite the contrary. "In the camp, for example, when someone is calling me, it's always of another nature. 'Come here you...,' a curse word," AHm told us. Indeed, one focus group began like this:

Q: Do you experience bullying sometimes?

A: Yes!

Q: Often?

A: Yes!

Q: Every week?
A: Yes!
Q: Every day?
A: Yes!

As we show below, negotiating racialized bullying and violence constitutes much of the substance of their everyday relationships, and it can very literally decide how they make their way to school or to the football pitch. ${ }^{2}$ For example, Rf told us that racialized bullying is such that when Lebanese bullies "say stuff about the Syrians, they make Syrian kids feel disgusted about going school." Not limited to students, she continued, even teachers "incite the kids against us" (cf. MEHE 2016, p. 15; UN 2019, p. 62 on racialized tensions and school attendance). A Syrian boy once "did an exercise wrong," Mf recounted, and the teacher "gave him [shit], she started yelling to him, "you, leave, instead of wasting my time, go back to your country, where you have ISIS

\footnotetext{
${ }^{2}$ A Human Rights Watch report (2016, p. 8) concluded: "Syrian families also describe widespread corporal punishment of children, as young as 5 , by teachers, school administrators, and bus drivers. Children face bullying, discrimination, and harassment on the way to school and in the classroom ... In some cases, teachers have not allowed Syrian children to use bathroom facilities at school. As a result, students have dropped out or parents have withdrawn their children."
} 
... It's better [more natural] for you to go back'." However, it was also clear that the young refugees reasoned things out for themselves to make sense of the ubiquity and banality of these racializations. Sf, an Iraqi girl, criticized teachers who pick on refugees at school, but added: "it's not that [Lebanese] discriminate or anything ... they just don't know what's going on in their country. Everyday life is changing around them, there are a lot of refugees now." In describing the fear on his route to the football pitch, Jm said: "they are in their country ... They can do anything ... [so they] bully the stranger." "They don't have fear," Y1m added.

There was thus remarkable consensus in their interpretations of this experienced racism as simply being part of the normal and inevitable subjections that form their social worlds. Still, subtle differences between the Syrians and Iraqis, to do with wider moral geographies, were also evident. Violent racializations crystallize in more direct ways for the Syrians, and even more so for those in the Palestinian camp. The Iraqi youth seemed slightly more detached and sheltered, perhaps more secure due to their positioning as Christians. The young Iraqis even analyzed the racism directed at Syrian refugees with a certain disinterest, and so could make relative valuations about their own positioning in Beirut's cultural and status hierarchies. And more, sometimes attempts by the Syrians in our groups to avoid the racializations could characterize efforts to "become Lebanese." AHm had begun half-mockingly, "to integrate better..." when M1m interrupted, "I change my voice, so they don't know me." AHm finished: "so we get into the spirit of the community." We did not notice this with the Iraqis. Their everyday social worlds seemed more bounded, more confident. Class also mattered. Mf's ability to speak Lebanese Arabic without a Syrian accent, as well as her fluency in French, allow her to move between worlds: "I am proud of myself [as Syrian]," Mf said, although she presents herself as Lebanese - "I don't like being differentiated." "She has split personalities," her sister explained.

\section{"All the stuff they say about us"}

"This person slaps you on the neck, that person talks shit to you...," M2m said. "They swear," "the mother, the sister...," "the sweary stuff," his friends added. The Syrian boys from the Palestinian camp finished each other's sentences. "'Oh look, this person is Syrian, don't hang out with him'," "'get away from us, don't walk with us,," AHm and A2m said. A1m and A1f experienced more bullying outside school; "for me, in school," Mf told us; "always on the street we get bullied," Jm, who is Iraqi, said. "In front of us they're very good, but behind our backs we feel they hate us," his classmate Nf continued. "When someone asks me if I'm Lebanese or Syrian, I feel embarrassed to say I'm Syrian, because of all the stuff they say about us," Mf observed, "they are disgusted by us." Mf told us that her friend accused her mother, who is a cleaner, of picking her clothes from the rubbish. "If you're Syrian you necessarily have to be poor," she added, "it's always Syrians who beg. I've never seen a Lebanese person beg. There is no Lebanese person who is poor and doesn't have anything. But you find Syrians poor and begging." In institutional settings and in quotidian intimate spaces, these kinds of racializations subjugate and politicize. They also police cultural boundaries and class hierarchies, often revolving around identifications of dirt and dirtiness as the classic materialities of place and belonging (cf. Campkin and Cox 2012; Douglas 1984, Chs. 1, 7). 
"A year ago, there was all this stuff about the garbage on the streets and in the water," Tf recounted with ironic frustration, "I heard Lebanese people say that when the Iraqis and Syrians came, all this stuff happened, as if to say we are the ones dirtying the country." Nf recalled a Lebanese teacher who was "much sterner" with the Syrians, and instructed the Iraqis to "stand further away from ... [the Syrians] because there are microbes and germs and I don't know what, so we don't fall ill ... There are disgusting people here'." This observation captures something of the sociology of how dirt and hygiene play out, as politicized racializations commonly construct refugees, particularly Syrians, as people in and from places of poverty and disgust. Two social workers with one of our partner organizations recounted the following: "once we worked with a child protection officer, and when she said 'hi' to children at the camp, she shook hands with [them]. And after she left - still in front of the children - she took a wet-wipe and cleaned her hands in front of [them]." The other social worker continued, "and when she left, they were really angry. It's disrespectful for them and it's very sensitive for the children. And she was in an upper position as a supervisor at the organization." A1m told us that he asked the teacher, "“why do you make us wear uniforms?' And she said, 'because if someone comes whose clothes are a little bit dirty, or a bit like this [referring to poverty or hygiene], nobody can make fun of them. You will all be the same, nobody will make fun of the other'." Perhaps most especially in schools and institutional settings, disease and poverty among refugees are readily attributed to "different standards of hygiene," as a psychologist cited above put it.

More, these racializations also make explicit reference to wider political resentments. "Sometimes a friend makes fun of me just because I'm a Muslim and she is Christian," A1f told us. "Sometimes they swear at us, sometimes they swear at Iraq, depends," Jm said. A1m explained that his friend hated Syrians because "they brought ISIS to Lebanon and they are the ones who cause problems and stuff." Rf recalled an exchange between Lebanese and Syrian students in school to illustrate how these deeply politicized resentments manifest:

One of the Syrian kids had made an effort to look good. The teacher started to compliment him and stuff. [This Lebanese kid] came over and started to say stuff like: 'Oh look how the teacher is hugging him and kissing him, I wish I was Syrian. Wow, these Syrians, they've started to take even our teachers from us, the teachers are hugging them and complimenting them now.'

We understood this encounter as drawing in wider social imaginaries. These can view those Syrian refugees who live in some of the poorest urban neighborhoods and among vulnerable Lebanese communities as taking local jobs and undercutting wages, even while being perceived as unfairly receiving aid and benefits (cf. Chit and Nayel 2013; Christophersen and Thorleifsson 2013; UN 2019, pp. 8, 11-12, 146). These entangled resentments are also suggestive of the tropes and discourses through which subjections continually re-form the young Syrians most especially as political subjects. The accusation, for instance, relayed by $\mathrm{Tf}$ who is Iraqi, that "you came to our country and ruined all of it'," does precisely this subjectivating work.

Racialized political resentments also operate across the Palestinian camp, where the political stakes are often higher, and where they more frequently come with physical threats and violence. M2m, a 12-year old Syrian boy, explained: "let's say 
there's a Lebanese and a Palestinian walking together, and a Syrian guy passes by...," M1m finished his sentence, “'yalla [come on], let's slap this guy'." M2m continued: “'yeah, let's slap him' ... they'll start singing a rhyme and making fun of him and hitting him." The Syrian boys are referring to the camp's common racializing chants or rhymes, and to the equally ubiquitous slaps on the back of the neck, often delivered in passing. In their own circles, these slaps are known to them as a form of play. But here they are bullied through the racialized appropriation of this normally affectionate play. The boys showed us the slap on the back of the neck - "they do it with force," M1m insisted, and it delivers the message that if you are Syrian, and "you hit someone, you're dead." Being slapped almost as a toy seemed to us to carry its own subtle form of menace, one that could feel deeply humiliating. In the Palestinian camp most especially, Syrians have become the new, weaker and racialized Other, perceived as receiving preferences at a cost to those refugee Palestinians (and Palestinians from Syria) who are already struggling in these spaces of politicized scarcity and exclusion. Here, the Syrian boys know that they are marked for violence, and group beatings are employed emphatically. They entwine with camp's calibrated power relations: "Palestinians hit you straight away," M1m told us, "but Lebanese people make fun of you more than they hit"; AHm then added, "there's people, and then there's people - Palestinians though, it's all of them"; but M2m specified, "with Lebanese, it's more 50/50." There was unanimity, though, that the Palestinians from Syria treat them as badly as the (Lebanese) Palestinians.

In these encounters, racism as subjugation is very literally inscribed on the young refugees' bodies. Beyond its discursive dimensions as symbolic violence, the physical violence that accompanies their daily lives is subjection and the exercise of power in its purest form. Racism and racialization are, of course, produced at particular social sites in the public sphere; yet "the body is the site of the racial experience," Fassin (2011, pp. 420,428 ) writes, because "the violence of racialization is exerted, experienced and performed through the body." Particularly with the Syrian boys living amid the Palestinian camp's political contentions, their bodies absorb the blows in ways that evidence the discriminations that inhere both within broader structural inequalities and within the smaller material realities of intimate, everyday relationships. To borrow TaNehisi Coates' (2015, pp. 17, 18; see also, p. 26) compelling formulation out of the US context, racism is a tactile and visceral "assault on your body," the product of a "system that makes your body breakable." This is because you are your body. We noticed that besides the physical pain involved, a disquieting sense of fear and threat, a potentiality of violence, also shaped their movements. It underlay the ways they held a tenseness and intensity. This, then, is how we ultimately understood the casualness of the racialized slaps on the back of the neck: they are a physical humiliation and stigmatization, the ultimate marking of the body. And they deliver most forcefully the political message that you - your body - are not wanted here.

Similar racializations and threats of violence also dictate daily encounters with Lebanese outside the camp, and here, too, we can see political subjects subordinated and in formation. "The Assyrians, the Syrian Assyrians, they're very strong," Y1m told us, "they bully the Lebanese people more than the Lebanese people bully others." M3m interrupted, it is "because there's a neighborhood there, it belongs to them." Jm concluded: "the Assyrians don't bully us, because we play football with them. They're 
good at football ... and we've become friends." These very specific cultural navigations are also suggestive of the confessional affinities between Iraqi Chaldean refugees and Syrian Assyrian refugees, who are also Christian. This is particularly the case among those in the wider diaspora, even if more recently the Chaldeans increasingly distinguish themselves against the Assyrians, not least within the Levant (Hughes 2015, Ch. 3). Thus, like the young Syrians in and around Palestinian camps in the west, the Iraqis in east Beirut's predominantly Christian areas spoke of the importance of walking in groups. "There are people whom we've heard about who have got hit. They bully them, five on one, what can one person do?" Jm explained. Asked how someone on the street would know to bully them, he offered this:

Ouff. First of all, we live in areas [and] they all know the areas well. Every alley, let's say, there are four or five or six ... I live in this area, they start to know me, I come and go from there. Secondly, we see them, and we talk to them sometimes.

In the everyday politics of their neighborhoods, then, the Syrians in the Palestinian camps contend with Palestinians, Lebanese and Syrian-Palestinians; and the Iraqis claim their own political subjecthoods in encounters with Lebanese, Syrians and Syrian-Assyrians across town.

Interpretations of what is at stake in these encounters take an important inflection in the racializing and sexualizing threats of violence directed at the girls. A2f, a Syrian girl on the borders of the Mar Elias Palestinian camp, put the experience bluntly: "There are a lot of threats to women. They'll always follow her, wherever she goes ... in narrow streets ... If the woman says something, they'll threaten her, 'if you did something, we'll say that you're making it all up'." The bodily fear that comes with these racialized encounters also means the potential for sexual assault, and indeed this reality continues to be widely seen around the Syrian displacement in Lebanon (cf. Anani 2013; UN 2019, p.190). A2f continues:

I was walking, and I realized someone was following me, so I stayed the course. He was saying stuff and I pretended not to hear. I ... was very afraid. So, I went up to the guy in front of me and pretended like I was going to start talking to him.

Interestingly, the boys seemed to understand something of the girls' experiences. AHm told us that "sometimes, if there are Sudanese women passing, they [the men] touch them." M1m observed the same for Syrian women: "they tap them, pinch them." "So many times, they would be catcalling the women walking," AHm elaborated. "She'd be in the shop, they'll all go to the shop, like three guys, they'll start brushing by her ... with their shoulders." As his male friends nodded in recognition, he described these gendered subjectivations metonymically: basically "they treat them like Sri Lankans."

\section{"If you're walking alone, you're gonna eat it." ... "Without salt!"}

These implied critiques of the subjugations shared by both refugees and migrants arguably contain a certain allyship in political alterity. The statement, "they treat them like Sri Lankans," in other words, is both a structural observation and a moral condemnation, spoken from a position of structural allyship. We see how this might 
work in the following example. The young Syrians and Iraqis sometimes struggled to articulate their emotions when describing their experiences of racialized bullying. Yet when one of our researchers shared her own story of having things thrown at her on her way to school because she was an "immigrant foreigner," their reactions were striking. In each focus group, they needed only a couple of words of translation before animatedly finishing the researcher's sentences, confident that they had understood what was going on. People like her "feel themselves weak," Mf declared, interpreting the bullied as collective "we." They easily and seamlessly identified how our researcher must have felt, and they offered the emotional vocabulary with which they had struggled when asked about their own experiences. "She's afraid," M2m said.

Mf: Can I ask what her reaction was? Did she run away?

Rf: She was afraid of [the bully's] reaction ... If I were in her place, I think I'd feel like I want to kill myself ... This sense that I really am like that. $\cdots$

AHm: It is violence. It's torture ... I'd be depressed all my life.

M1m: She wants to die, she wishes for death ... [she thinks]: 'I wish I don't exist, so I don't have to see stuff like this.'

The young Syrians, in particular, perfectly recognized the pain of subjection, and the shame and humiliation that racialization can produce. "It's like they're hitting her, and she can't do anything about it," was AHm's somber assessment of her story, as he identified in her feelings that might have been familiar to him. They immediately understood our researcher as feeling "small," perhaps even wanting to "cease to exist" in those moments. They were able, in other words, to articulate the presumed subjective experience when it was presented as an opportunity for mirrored empathetic understanding.

They then switched to how they would respond, and offered sympathetic advice, ranging from the humorous to the submissive to the confrontational:

A2m: I'd have gone and fought with them.

M1m: I'd bring spare clothes to change into once I got into school.

Y2m (sternly, to M1m): Do you think she had any idea they were going to hit her [with eggs]?!

AHm: I'd sit and cry.

A2m: I'd hit.

M2m: I'd bring [something] and hit them with it.

A2f: Me, if they were so upset by me, I'd fight them in a way. I'd stay there [in their faces]. As much as they're upset with me, I'll stay in front of their face, I won't go anywhere ... If I were her, and they threw eggs at me, I'd just throw tomatoes on them.

A1f: If I were her, and they threw eggs at me, I'd throw tomatoes at them. 
A1f: Yeah, but onions don’t explode.

A1m: I'd just keep walking.

We understood these responses, offered almost as collective advice, as echoing what Herzfeld (1997, pp. 2-4) theorized as cultural intimacies: nation-building cultural engagements at sites of social intimacy - the "rhetorics of everyday social life" - are "aspects of a cultural identity that are considered a source of external embarrassment but that nevertheless provide insiders with their assurance of common sociality"; and they thereby become "forms of rueful self-recognition." Around these shared vulnerabilities - "sore zones of cultural sensitivity" in Herzfeld's (1997, pp. x, 6) formulation - and beyond their theorized nation-building functions, we also saw these cultural intimacies as imaginative forms of political resistance to certain forms of subjection. When M1m told us, "if you're walking alone" on the streets of the camp, "you're gonna eat it," and his friend shouted, "without salt!" it was clear that they not only understood and shared their own status vulnerabilities within the social and moral hierarchies around them, but that they could also mobilize or draw on these vulnerabilities in the constitution of a resistive political subjectivity.

In this way, the contents of the racializations described above arguably come to have an altogether different material significance. They become an instrument of subjective defiance, used to fortify against the produced subjectivities that come with the oppressiveness and claustrophobia of being a "dirty Syrian refugee," for instance. The young Syrians and Iraqis recognized their shared pain at exclusion; but they were also able to place perceived social flaws and status vulnerabilities into the realm of the humorous. M2m, a Syrian boy, recounted his experience of being beaten by four Lebanese boys during the changeover of school shifts. Both his story and the banter around it in the focus group were remarkable for the emotive force of their cultural intimacy:

M2m: Once I was going to school. When we go in, the Palestinians and the Lebanese leave. These Lebanese and Palestinians always beat us ... There were four boys walking, the first one threw water at me, I didn't do anything, just kept walking. The second tripped me and the third hit me here [gestures]... so I...

A2m: And the fourth?!

M2m: So, I went and spoke to them. I hit the first one. The second one attacked me from behind. The first one, I was grabbing him from the front and he's hitting me. The second one grabbed me from the back and is hitting me.

A2m: And the third?!

M2m: He made me fall to the ground, and the other two started to join up. The fourth one is big; he's 14 years old. He came and grabbed me, stood me back up and hit me. I hit him back. He's fat. I hit him, nothing happened to him.

M1m: In his belly!

M2m: He hit me between my legs.

M1m: They [basically] made them fly!

$\mathrm{M} 2 \mathrm{~m}$ : So, they put me on the ground, it was rainy, so there was a stream of water; they threw me in it. That hurt a lot. They kept kicking me, threw water at me, and then ran away. The principal and the teacher came, and they took me to the hospital, and it turns out I had a broken egg. 
"What's a broken egg?" Y2m asked. M1m replied: "come on! They pitted his olive!" The group descended into uncontrollable laughter. Our initial surprise that a young teenage boy would expose his vulnerabilities and weaknesses, not only to a foreign research team but also to his peers, gave way to a certain understanding when we saw them laughing with him. Being beaten without the ability to defend oneself loses some of its shaming and subjugating qualities when understood against their shared experiences as the racialized and bullied. M2m did not see himself weak or cowardly, and neither did the others. They believe that racialized violence happens because refugees are structurally oppressed, and Syrians foremost among them.

Put more formally, then, these kinds of encounters are suggestive of subjectivation's ambivalences at the site where subjects are dynamically formed and come into being. Their recognition of being produced as refugee subjects - dirty, weak, bullied - becomes a condition for the possibility of their own claim to political subjecthood. Thus, the reliance on cultural intimacies is in this way generative of resistive subjectivities. If one effect of the experienced racism, as we argued above, is to subjugate, now, through the operation of cultural intimacies, even these violent racializations can sometimes be eclipsed. The subjective rendering of their experiences from humiliating to humorous agentially wrests back not only a small measure of power, but it might also be read as a kind of claiming of a newly imagined "us" as "the bullied." It hints, in other words, at a Rancièrian-inspired reading of political subjectivation as they disrupt the subjugating ways in which racial meaning and significance attach to them as Syrian refugees.

\section{"Sometimes we act, but with caution"}

We saw the young refugees as agential political subjects most unambiguously in their varying efforts to reshape experienced racism by claiming back a sense of dignity and control. They weigh up what they value most in their everyday realities. Enduring a beating or humiliation, for instance, may be worth it if it allows you to play football. Navigating these racializations could range from avoidance by not disclosing who you are - "she's Syrian, but she says she's Lebanese"- to ignoring them, to a submerged but identifiable anger and resentment at the injustices. Bullying "wouldn't happen to me," Mf said assertively, "because I don't shut up to these things. I won't make mistakes, for sure, I'm going to be more aware [i.e. mature] than the bully ... I'll speak to someone older than him to make him understand things." A1m, a Syrian boy who lives on the city's outskirts, told us this story:

In school, once, this guy told me, 'you're Syrian.' I didn't pay any attention and left. He came back to me later and said, 'I'm sorry.' Because if I went and hit him, he's going to think that the Syrians are being too proud of themselves, taking their comforts and thinking that their country is the best country ever ... He's going to go and complain to the administration straight away, and the administration is going to expel me. I want to give him the opportunity to think about his mistake and come back and apologize to me himself. 
More typically, though, and because racializations are accompanied by the fear or threat of physical violence, response options amount to "nothing, we can't speak," as M2m put it. A2m told us that the most common strategy was to "basically ignore it." Jm said: "if we respond, then the problem will be bigger, so we ignore it, no worries ... Sometimes we respond to them, sometimes we hit them, but most of the time we don't say anything." "We can't say a word" AHm explained, "if you hit someone, then all of them will attack you - all of them." If girls or women confront the bullies, he continued, then they will tell you to " bring your husband or your brother, let him come say something'." And, Y2m added, "if they do bring someone, they'll beat them up."

"They walk in formation like a gang," AHm then explained, "so we started to do the same to defend ourselves." "It all depends on who's got your back," he said, so if "someone comes and hits a Syrian, I try to defend him, but as soon as I try to defend him someone else comes. Over there, there was someone who used to defend me, but now he's in jail." On a different scale of identity, of course, these experiences are very similar to urban street gang rules, not least in the ways in which groups coalesce in identifiable spaces policed by threats of violence that can also enable resistive challenges to transgressions (cf. Rios 2011).

Noting, too, that they were "a bit addicted to football," M2m offered this:

I was walking, and this guy's shoulder touched my shoulder, he came and hit me. I started to bleed from the mouth. I went and spoke to my mum... My mum spoke to my dad, so they stopped letting me leave the house ... I told the guy to come to my house and apologize to me, so they allow me to leave the house ... Had he not come over and apologized, they would have never let me leave the house again [to play football].

Racializations also occur in schools, and they include both verbal abuse and physical violence. Asked about the teachers, A2m said, "they're not good with me." "All my teachers were like pigs to me," M1m told us. And M2m added, "the Lebanese teachers are arrogant." Corporal punishment is relatively common across Lebanese schools generally, but the added stresses and strains on a system that struggles to afford qualified teachers for refugee education, particularly for the second shifts, means that corporal punishment in the classroom early on became a common - and racializing instrument for disciplining Syrian refugee students especially (UNICEF 2012, p. 31). As a recent UN Report (2019, p. 146) concluded: "violence in schools, physical, psychological or sexual remains a reality for children in Lebanon." But Syrian refugee children have been "more exposed to political and sectarian pressures," (UNICEF / Save the Children 2012, p. 20) including violence, than Syrian adults. This has been most acute among boys aged between 10 and 14, who experience high levels of verbal and physical abuse from teachers and students (UNICEF 2012, pp. 18-22, 31, 40).

The young refugees seem to grasp the disjuncture, however, and in their schools and humanitarian organizations they sometimes find room for maneuver by asserting themselves as rights-bearing or protected subjects. AHm very specifically pointed out that the teachers "are not allowed to raise a palm at us. UNICEF has banned this. Even slaps are banned." The recognition that they have rights opens a space for recourse to humanitarian or other formal institutional protections accorded to minors, and particularly to refugee minors. M1m 
understands this power: "at school nobody likes me, because when they hit me, I go to the teacher and act as if they've broken my leg or something, and immediately they get expelled.” Or AHm's story from the Palestinian camp:

I got into a fight with [my teacher]. Because we were mostly Syrians in my class, she started to make us feel like she's doing us a favor by teaching us ... 'I'm doing you a favor.' So, I got out of class and went straight to the supervisor. The next day UNICEF called her, and she apologized to me.

Whether this occurred precisely as described is perhaps less important than the fact that AHm imagined or wanted it to be like this. And indeed, Nf, an Iraqi girl, outlined a similar response to being racialized because of the garbage crisis, or to witnessing teachers abuse Syrian students as "disgusting" in the classroom:

Sometimes we act, but with caution: we gather everything, get me? So that we have enough evidence ... I genuinely did this once, I brought everything to the organization, and I spoke about everything ... They are taking action. Today and yesterday too. Ms. [...] told me she would look into the issue.

The young refugees envisage the possibility of recourse, understanding perfectly which subjectivities are produced and by whom. Yet in eclipsing these, even if only in their hopes, they also emerge as moral agents attempting to push the systems to do better. We might see these moments in more abstract terms, in other words, as paradigmatic sites of the overlapping subjectivations that characterize experiences of displacement, and therefore also as sites for the agential constitution of political subjectivities.

This includes the important moral or ethical dimensions of their navigations. We see these concretize, for instance, in the young refugees' interpretations of their treatment in the public schools under MEHE's strategy for Reaching All Children with Education (RACE). Among other things, RACE mandates that the two-shift schools fully include both Lebanese and refugee students within their targets (cf. MEHE 2016; UN 2019, pp. 55-58). But the students contrast these schools to some of the more informal or ad hoc educational spaces outside of MEHE's jurisdiction. Sf's explanation is worth quoting at length:

[In the mixed public school] the teacher, you can't speak to her. She's very stern. Their treatment [of us] is not good, you say something, and she responds in a not nice way... [In the community center] if something happens, we come back to air our grievances... These public schools... they don't care if we learn or don't learn. Even the number of students is quite low; they don't go because their treatment of them is not nice... All they [these schools] care about is to take the paper from the UN, so that UNESCO or I don't know what it's called, so that they can tell them [UNICEF or UNESCO] that, 'yes, we have students coming,' so they receive the donations. Other than that, there's basically no school, almost none of us are going, but for them they took the paper and copied it, all of ours, even those who didn't go. I'm speaking honestly. This is how they operate. They don't care at all, the principal always says, 'you don't want to come, don't come. I don't care.' 
They made these ethical discernments with considered reference to the normative or moral distance between humanitarianism's educational mandates as theoretical, and their embodied experience of schooling as lived.

This is important for two reasons. First, in marginalized and politically constrained contexts, these small, moral claims to dignity, or imagined gestures of defiance, are also ways of trying to influence the forces that subject, oppress and define (cf. Chatty 2010b; Marshall 2013, pp. 63; 2014, pp. 290-295; Nguyen-Gillham et al. 2008, p. 295; Rios 2011, pp. 104-107, 109-112, 116). Palestinian youth, for instance, acknowledge the violence and daily cruelties of occupation, but they respond with "steadfastness" (sumoud) as part of a community in collective struggle and resilience (Marshall 2014, pp. 290-294). In the US context, too, Rios (2011, Ch. 5, and esp. pp. 97-98, 111-115) shows how in the face of a racialized criminal justice system, young black and Latino youths often commit petty provocations and small "crimes of resistance," which might be misrecognized as stupid by authorities, but which nevertheless accord them a (sometimes self-defeating) sense of dignity and control. Indeed, as Nguyen-Gillham et al. (2008, p. 295) conclude in their research with Palestinian refugees, "to be passive politically is humiliating while even minor political gestures restore a modicum of dignity." These are very different social worlds, to be sure, and of course vastly different conditions of political constraint. Yet there is a shared phenomenological quality to their self-understandings. Resistive political and moral subjectivities can form around defining struggles that require making sense of and navigating politicized social worlds - in this case both the racialized spaces that routinely marginalize and mark for humiliation and those of humanitarianism, which depoliticize the obviously political.

These ethical discernments are significant for a second reason. When a young refugee is violently racialized from inside the moral social imaginary as a "dirty Syrian," we also see how the political (sub)alterities of forced displacement are deeply embedded in a distinctive space of values. It is a space navigated by the moral subjectivities and commitments that inhere to human agency, which we understand in Charles Taylor's (1989, p. 28) minimalist terms like this: "[t]o know who you are is to be oriented in moral space, a space in which questions arise about what is good or bad, what is worth doing and what is not, what has meaning and importance for you and what is trivial and secondary." Indeed, across both Beirut's neighborhoods and camps and its humanitarian spaces, the young Syrians and Iraqis perfectly understand which interpretive frames and subjectivities are valorized, when, and by whom. And they can sometimes steer or imagine their ways through them to enable the possibility of empowerment, self-regard, and self-definition.

In this sense they navigate forced displacement's constraints as political and politicized subjects, but they also do so with the reflective agency of its moral subjects. Very occasionally, too, they revalorize and eclipse these subjections to reimagine themselves and "the what ought to be" on their own terms. Whether their efforts succeed or not, and, indeed, even if some accounts are perhaps more bravado than fact, sometimes they understand themselves as going beyond the kind of justice typically defined by humanitarianism. They also seek to redefine what humanitarian justice should even look like given the ethical order around them. In addition to expressing certain moral subjectivities, then, these commitments also gesture at the possibility of seeing very distinctive processes of political subjectivation in the narrower, Rancièrian sense. 


\section{"In my heart, there's something like a fire - it burns"}

If navigating experienced injustices could mean asserting a (new) rights-bearing subject into this moral space, then as noted above, the most common way of making sense of experienced injustices was to reason them out as being intrinsic - indeed normal - to the social world of forced displacement. "We can't say a word," AHm told us, "because nothing comes out of the Syrians [i.e. they are powerless]." Or M1m: "Syrians are oppressed. Simply." This is a structural observation. But it also has embedded within it the possibility of interpreting an experienced racialization as shared and relational, rather than in personal or individualized terms. Nearly all located the injustice of racism not in individual hatreds - "there's people, and then there's people" - nor in the subaltern subjectivities and resentments that can be produced by powerful historical oppressions and their resultant invisibilities and inequalities. They instead understood the injustice of racism as constitutive of the politics of displacement, wherein power and privilege explain why they "bully the stranger," as Y1m had put it. This is important sociology. It conceives constructed inferiorities and ascriptions as artifices of refugee-ness, and not in terms of personal or individual flaws. Syrians are not oppressed because they are inherently inferior, the young refugees reasoned. Rather, refugees are treated as inferior because they are structurally oppressed. In this historical moment, and in this particular place, refugees happen to be Syrian. Fields and Fields (2012, p. 121) explain the underlying sociology: "[a] commonplace that few stop to examine holds that people are readily oppressed when they are already perceived as inferior by nature. The reverse is more to the point. People are more readily perceived as inferior by nature when they are already seen as oppressed."

Still, embedded within their accounts of these daily experiences of injustice, there were plenty of unmistakably anguished feelings of powerlessness. "If someone calls us like that [racialized swearing], do we get depressed? Or do we throw everything behind us?" AHm asked. Then he captured it concisely: "for me, in my heart, there's something like a fire - it burns ... But I can't do anything. I go to my room, on my own, and I go crazy." Asked if she feels herself Lebanese, Mf, who struggled with whether to present herself as Lebanese or Syrian, answered: "it's not going to make a difference what I feel myself." She recognized this reality as a deep injustice in terms of how she could see herself, and added, "it's more about what your roots are ... If you were Syrian, it means you are Syrian, not Lebanese." We noticed, too, that A1m, a Syrian boy, was frustrated to the point of lashing out at the teachers' silence or indifference to the racism that Syrian students experience in his school.

More, both in their appropriation of humanitarianism's subjectivities and in the everyday stories they shared, we found that they consistently maintained a meaningful distinction between their descriptions of painful experiences of racism and injustice, and their normative understandings of what these experiences should or could be. "I would have liked once to walk with a Palestinian or Lebanese person, and for them to respect me and to speak to me like a person," M2m said. Or A1m to a Lebanese friend: "why do you hate Syrians? You should know better." Indeed, Mf's bold assertion that "animals don't discriminate!" is at once a pithy assessment of the social role of racism, a normative claim to racial justice, and an effective reversal of the subjection. Injustices were not accepted, to be sure, but 
one way to reason through them was to not allow them to become fully defining. Put differently, both in their recognition of the structural grounds for experienced injustice, and in the moral evaluation of those encounters, some resisted a particular form of subjection that "imposes a law of truth" (Foucault 1982, p. 781), namely that they are - and that they should view themselves as - inherently inferior.

Significantly, however, within a politically constrained and racially demarcated social world that overlaps with that of humanitarianism, resistance to injustice also found expression in an interiorized refusal to be defined either by racism or by humanitarianism's ethics. This often simply took the form of an internal commitment or posture. Mf, a Syrian girl, told us this: "I used to feel [small or not good enough], but I became stronger with time. I started to ask, 'why [do I feel like this], I should be stronger' ... I used to feel this small in front of them, but now, no." We did not understand this, or other similar postures, as mocking or subverting the system, as Rios's (2011) data suggested. Rather, they seemed to relentlessly mock the racism itself, ridiculing "all the stuff they say about us" until it is dismantled, and the sting of injustice loses its force. Thus, conceiving political resistance as also residing in these interiorized forms allows two observations. Most immediately, we see the less visible, silent or subtle ways in which the political and political subjects find expression and disrupt what seem like over-defining subjectivations. And secondly, through the interiorized commitments of political subjects and subjectivities, we also glimpse something of the structural and takenfor-granted workings of the ethical order that sustains refugeedom as human condition and experience of (sub)alterity.

\section{Refugeedom and its political subjects}

"We look through subjectivity," Biehl et al. (2007, pp. 15-16) write, "not to theorize an intangible Subject but human conditions." With forced displacement's political and moral subjectivities in view, attention shifts away from categories and processes, towards interpretation of the valorizations and meanings that refugees attach to their multiple subjecthoods. With respect to refugees' political subjecthoods especially, humanitarianism can often operate with great psychological acuity but almost total sociological blindness. ${ }^{3}$ The normative clarity of Fassin and Rechtman's (2009, pp. xii, 160) call for "re-politicizing the victims" might also recognize that not only humanitarianism's ethical landscape but our research, too, could better theorize "the political" of forced displacement. We might better attend to racism and discrimination, injustice and resistance, political oppressions and coercions, and the everyday brutalities of civil societies. We had initially undertaken this research with the intention of theorizing the refugees' experienced racism rather narrowly. But in making sense of the data, we realized that the young refugees had actually showen us the ways in which they are formed, and form themselves, as complex political subjects against the constraints of their forced displacement. This challenged us to re-route our analysis toward a better

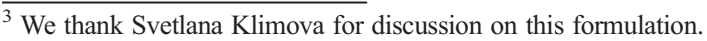


understanding of the subjecthoods of those living refugeedom's conditions of political alterity and constraint.

We found that as they navigate forced displacement's politicized constraints on what "self" is possible, the young refugees constitute themselves as political and moral subjects in core and defining struggles with racialized violence, discrimination and exclusion. We noticed, too, that in trying to redefine the terms of their own forced displacement, occasionally they could revalorize - and then eclipse - those complex and entwined subjectivities manufactured by humanitarianism and by racism. In these moments, they seemed to briefly claim a repoliticized subjecthood, one unconnected to humanitarianism's categories and not contained within the normal politics of forced displacement. We thus offer three specific and substantive findings. First, the young refugees articulated their experiences of racism as inhering in what they understood as forced displacement's structural torsion, whereby they interpret racialized injustices as being constitutive of, not contingent to, their lived everyday. Second, we found more expansive - if highly situated - expressions of what resistive political subjectivities could look like viewed from their perspectives of subjugation and relative powerlessness, and from within those structural constraints that they struggle to influence. And third, the young refugees pragmatically deployed imaginative and scrappy bits of resources and opportunities to gain a sense of control and self-regard. Here, as reflective moral actors, they pushed against the subjectivating logics of camps, streets, schools and humanitarian organizations. They often took the measure of the distance between "the what is" and "the what ought to be" of their social worlds. In doing this, they could sometimes re-appropriate humanitarianism's produced subjectivities to push practitioners to realize ideals of non-discrimination and to be recognized as political and moral subjects, not only as neutral beneficiaries.

Some of our data, in other words, hint at another route for repoliticizing theorizations of the "refugee subject." This moves us a little beyond critical (refugee) humanitarianism. Fassin (2012, p. 222) writes that humanitarianism "contributes to forming victim subjectivities to which social agents must make reference, including when they seek to make a demand for justice heard - in other words, precisely when they wish to move beyond ... [humanitarianism's] logic of compassion." It is possible to take over humanitarianism's ahistorical subjectivity "precisely in order to demand what ... [has been] denied: the status of political subjects" (Fassin 2012, p. 222). On the basis of the young Syrian and Iraqis interpretations of their experiences, however, it is worth asking if sometimes they might be claiming themselves as rather different political subjects than we imagine, not least vis-àvis humanitarianism. As we saw above, on occasion they pushed institutional actors to be more accountable to their professed ideals of neutrality and non-discrimination. These navigations were ways of reclaiming those subjectivities that formally structure humanitarian protections but that are not always enacted. Thus, into the ethical or normative distance between their assessments of racializing experiences and their desire for things to be different, or more just, when they could, they leveraged the political and ideational possibilities of humanitarianism's subjects.

In this way, then, a rights-holding subject reflexively navigates and deploys produced subjecthoods not only in search of a just outcome, as Fassin (and Feldman 2018) rightly argue, but equally, and perhaps as significantly, in a morally empowering attempt to change the unchangeable. Put differently, they deploy the subjectivating constructs that humanitarianism imposes, but not just instrumentally to achieve justice 
or to claim a political subjecthood. Sometimes they also do so as very reflexive moral agents who are trying to reshape the subjectivations of the system itself, and thereby redefine the terms of their own forced displacement. This is to suggest more broadly that forced displacement's social worlds form the ground on which subjectivities and agency are constituted. And that analytically distilling its key subjectivations might open up new ways of thinking about refugee subjecthood and forced displacement generally. We thus situate the young refugees' navigations of their social worlds in a more explicitly political and analytic frame - refugeedom ${ }^{4}-$ which we now abstract into a simple theoretical architecture of subjectivations and produced and constituted subjects and subjectivities. We imagine a situated and embodied (young) refugee inside a theoretical triad, which represents the embodied experiences and subjectivities of her racialized and humanitarianized social world.

The first point of refugeedom's theoretical architecture is humanitarianism's production of the refugee as a rights-bearing or juridical subject. Defined by the categories and practices of crisis or refugee humanitarianism, it draws from global humanitarianism's legal categories, from human and refugee rights, and from children's rights. These are vernacularized and concretized by local aid organizations, and state and municipal authorities. We saw something of this, for instance, when Nf, an Iraqi girl, and AHm, a Syrian boy, had sought recourse to school authorities and to UNICEF to claim justice for racisms experienced in the classroom. They did so precisely by claiming themselves humanitarianism's rights-bearing subjects. This produced juridical subject, of course, has a traceable historical lineage in liberal universalism and in Western modernity's "humanitarian reason" (Fassin 2012). It is a subjecthood, in other words, rooted in a modern form of subjectivity.

The second point of refugeedom's theoretical architecture involves not the juridical, but the refugee as the suffering subject, the victim of trauma and loss. Here we see the vulnerable and resilient, innocent, social-psychologized subject who is in need of protection, care and compassion. Constituted through the ordinary bureaucratic practices and visualities of refugee and crisis humanitarianism, the refugee becomes a depoliticized and dependent beneficiary of humanitarianism, media constructions and of wider social sympathy. We might see this, for example, in how M1m, a Syrian boy, had faked a broken leg after a beating in order to claim himself subject to the protections and care afforded to all vulnerable minors. This is a modern inflection of an older form of subjectivity. The twenty-first century's suffering, apolitical and bureaucratized subject of humanitarianism is distinguishable from the equally suffering but aestheticized exile and émigré of earlier centuries (Malkki 1996). As Malkki (1995, p. 513) beautifully observed, “"exile' connotes a readily aestheticizable realm, whereas the label 'refugees' connotes a bureaucratic and international humanitarian realm." There is a different kind of produced victimhood and vulnerability here, in other words. Under this construction, humanitarianism's apolitical but suffering refugees are modernity's abandoned subject of sorts, homines sacri living liminal lives in "zones of indistinction" (Agamben 1995; Agier 2011).

Still, if living the humanitarian condition is about the everyday fundamentals of getting on with life when displacement perdures (Feldman 2018), it is also true that lived

\footnotetext{
$\overline{{ }^{4} \text { We depart from Gatrell's (2017) }}$ use of refugeedom. He defines it as the activities, organizations and networks of refugees which form matrices of relations and practices.
} 
refugeedom is wider than the humanitarian condition. At the edges of humanitarianism are states and civil societies. Thus, the third produced subject of refugeedom's theoretical architecture is the politicized, Othered or racialized subject. It is the refugee as political (sub)altern. Formed through the exclusions and racializations of living in politicized spaces while carrying the social weight of the assignation "refugee," they are also subjugated by border regime practices. This was the most visibly embodied dimension of the young Syrian and Iraqi refugees' daily lives in schools, football fields, streets and camps. It was an experience of subjectivation as pure subjugation through the physical marking of exclusions on the body. Politicized and racialized violence produces refugees as racial subjects, both as subjection and as subjectivation. This form of political subjectivity, too, is modern. Even if it arises with the legal and humanitarian invention of "the refugee," its lineages are also rooted in the historical emergence of the nation-state and citizenship, and in global historical formations of imperial and colonial hierarchies. The phenomenology here is not "bare life," then, but the experience of the post/de/colonial subaltern. The refugee is less the quintessential modern subject in Arendt's (1943) or Agamben's (1995) sense, and more in Hage's (2016) sense: she embodies something of the anti-colonial challenge to modern global hierarchies. For both the refugee and the postcolonial, agency and subjectivity are shaped by differentials of power and by the structural realities of institutionalized, political Otherness and (sub)alterity.

This architecture of refugeedom's subjectivations and its subjects - the juridical, the innocent and the suffering, and the racialized and Othered - form the repoliticized theoretical and ethical ground on which multifaceted subjecthoods are constituted. Once a person flees their home and enters another country, they become an internationally protected "refugee," with all the rights, entitlements and subjectivations that this assignation and its lived realities can carry. Refugeedom is, in short, a bureaucratic referent, but it also bears the weight of global and local contestations and of political worlds and moral geographies. Thus, in more formally theorizing forced displacement as a lived human condition of political (sub)alterity - one among many others, to be sure - we seek to capture something of the phenomenology of what this experience comports and forces upon the individual whose life is now in almost every way defined by it. Our data speak to the weight of refugeedom's subjections, but also to their possibilities. The subjections that inhere in refugeedom produce "the refugee subject," but they also generate the possibilities for the emergence of an entanglement of subjectivities, both produced and constituted. This theoretical triad of subjectivations, as we seek to define it, becomes a distinctive ground for the contestation of political (sub)alterities, which are not at all disembodied from complex and particular histories. As such, it becomes the terrain of the political and of the ethical. Its subjectivations and constituted subjects enter into a space of contention, to re-quote Rancière, as if a "conflict over the existence of a common stage and over the existence and status of those present on it" (Rancière 1999, pp. 26-27).

More, if this space of contention produces political and other subjects, the "refugee subject" can also re-appropriate herself not only of political but also moral agency. It is to suggest that, viewed through the ways in which (the young) refugees move through these entanglements, refugeedom also contains within it an ethical space of value and sensibility. This becomes the ground on which moral meaning and significance attach to agency and subjectivity. We understand this in Charles Taylor's (1989, Ch. 1 and passim) wider sense of the moral social sphere. The moral 
and the political of being human are inextricable from wider socialities. Refugeedom, too, is an ethical social world as much as a lived human condition, with its own moral horizons or frameworks of values which in turn form the social, the political and the "self." As Taylor (1989, p. 27) argues, it is "the horizon within which I am capable of making a stand." This is at the core of what constitutes life as a human being experiencing forced displacement. The refugee "self" is bound up with those deeper values that give direction and structure to ordinary living and that determine the small and big deliberations that make up a life. Understanding young refugee selfhood and refugeedom in these terms, we can, with Taylor (1989, Part III), affirm a sociology of their ordinary, everyday navigations, but not dislodge their deliberations and commitments from the deeper moral and aesthetic-ethical frameworks that underpin them.

As we move, then, from category to subjectivity, we move also from forced displacement as descriptive of complex processes involving "a mixed category of peoples sharing a certain legal status" (Malkki 1995, p. 511), to a theorization of refugeedom as a distinctive, politicized human condition or form of human experience generative of certain political and other subjects and subjectivities. To be sure, we do not claim that this is in any sense a single, shared or trans-historical condition, setting or experience; we hope to avoid this essentialism. We similarly do not wish to generalize from the stories we gathered from a group of young Syrian and Iraqi refugees in Beirut. But perhaps viewed through their entangled but identifiable subjectivations, capturing a set of produced subjectivities and their contestations makes a modest contribution to better understanding the "refugee subject" and its political embedding. Our conceptualization of refugeedom is far removed from theorizations of displacement as "bare life" or its zones of abandonment. And it goes beyond those that argue that refugees are also political actors. But we equally hope to move understandings of the life of the refugee a little beyond Foucauldian readings of subjects and subjectivations. We have sought to offer an interpretive or subjective route to repoliticizing our theorizations of refugees and forced displacement that allows for the new, and as yet unimagined, stretching of subjective space.

Our data, in fact, occasionally hinted at the possibility of seeing displacement's political subjectivations in Rancière's more expansive terms. That is, in certain moments we glimpsed the young refugees as "political subjects," understood in a Rancièrian sense of political subjectivation. Their small but notable acts of resistance towards racist bullies and classroom racializations, and their attempts to push against the humanitarianism's limitations, occasionally gestured at new or redefined subject spaces. When Nf said that she would gather evidence of discrimination and present it to authorities, and her friend laughed ironically and asked, "why do you gather evidence? Is your existence a crime?" she is speaking as a political subject in characteristically Rancièrian terms. She is speaking as if verifying an axiomatic equality or an "essential egalitarianism." It is a process of subjectivation that involves opening up a subject space not contained within the consensual field of refugeedom's politics. She is not claiming this equality as a refugee, in other words, or even within the register of human rights, but on an even more fundamental basis. In refusing "to feel small" in the face of racism simply by asking herself why she should feel small or worthless, Mf dismantles her very subjugation by revealing its manufactured contingencies and constructions.

We might even more formally say that in this questioning she is in effect rejecting an identity imposed by the body social, and instead stepping out of the consensual space with a 
new subjective commitment based on a claim to an underlying equality (Rancière 1999, pp. 16-17; cf. 1992, p. 62). The young Syrians and Iraqis emerge as agential political subjects through the classic ambivalence that constitutes "the bind of agency," that is, as both "a resistance that is really a recuperation of power" and "a recuperation that is really a resistance" (Butler 1997, p. 13, emphases original). Yet, in the ways in which they understand their actions, postures and attempts to redefine what "self" is possible, they also briefly reconfigure the very subjectivations and subject spaces of refugeedom that we have just theorized. Only in certain moments, perhaps, they claimed themselves as "subjects that did not have the rights that they had and had the rights that they had not" - a dissensual "putting two worlds in one and the same world" which belongs to the agency of a political subject (Rancière 2004, p. 304). And which belongs to the subjectivities of refugeedom.

Acknowledgements The authors would like to thank the research team - David Anderson, Mary Holmes, Marie-Eve Hamel and Katherine Baxter; and for discussion and comment, Svetlana Klimova, James Kennedy, Kay Tisdall, Emma Davidson, and the anonymous Reviewers. We are also deeply grateful to our partner organizations in Beirut, and to the young refugees who, in sharing their stories with us, also gave us an important part of themselves.

Funding Fieldwork was funded by The British Academy (Academic Grant Number SG152525).

\section{Compliance with ethical standards}

Conflict of interest The authors declare that they have no conflict of interest.

Open Access This article is licensed under a Creative Commons Attribution 4.0 International License, which permits use, sharing, adaptation, distribution and reproduction in any medium or format, as long as you give appropriate credit to the original author(s) and the source, provide a link to the Creative Commons licence, and indicate if changes were made. The images or other third party material in this article are included in the article's Creative Commons licence, unless indicated otherwise in a credit line to the material. If material is not included in the article's Creative Commons licence and your intended use is not permitted by statutory regulation or exceeds the permitted use, you will need to obtain permission directly from the copyright holder. To view a copy of this licence, visit http://creativecommons.org/licenses/by/4.0/.

\section{References}

AbouAssi, K. (2012). Hands in the pocket of mercurial donors: NGO response to shifting funding priorities. Nonprofit and Voluntary Sector Quarterly, 42(3), 584-602.

Agamben, G. (1995). We refugees. Symposium, 49(2), 114-119.

Agamben, G. (1998). Homo sacer: Sovereign power and bare life. D. Heller-Roazen, trans. Stanford: Stanford University Press.

Agamben, G. (2008). Beyond human rights. Social Engineering, 15, 90-95. https://novact.org/wpcontent/uploads/2012/09/Beyond-Human-Rights-by-Giorgio-Agamben.pdf. Accessed 21 Apr 2019

Agier, M. (2002). Between war and city: Towards an urban anthropology of refugee camps. Ethnography, $3(3), 317-341$.

Agier, M. (2011). Managing the undesirables: Refugee camps and humanitarian government. D. Fernbach, trans. Cambridge, Polity Press.

Allan, D. (2013). Refugees of the revolution: Experiences of Palestinian exile. Stanford: Stanford University Press.

Anani, G. (2013). Dimensions of gender-based violence against Syrian refugees in Lebanon. Forced Migration Review, 44, 75-78. 
Alsharabati, C., \& Nammour, J. (2017). Survey on perceptions of Syrian refugees in Lebanon: Between resilience and vulnerability. Institut des sciences Politique USJ. https:/www.unhcr.org/lb/wpcontent/uploads/sites/16/2017/03/Perception-Study-USJ-Feb17.pdf. Accessed 25 Apr 2019.

Appiah, K. A. (1985). The uncompleted argument: Du Bois and the illusion of race. Critical Inquiry, 12(1), 21-37.

Appiah, K. A. (1996). Race, culture, identity: Misunderstood connections. In K. A. Appiah \& A. Gutman (Eds.), Color conscious: The political morality of race (pp. 30-105). Princeton: Princeton University Press.

Arendt, H. (1943). We refugees. In The Jewish writings (pp. 264-275). New York: Schocken Books.

Bakewell, O. (2008). Research beyond the categories: The importance of policy irrelevant research into forced migration. Journal of Refugee Studies, 21(4), 423-453.

Barnett, M. (2011). Empire of humanity: A history of humanitarianism. Ithaca: Cornell University Press.

Beck, M. (2018). Contract slavery? On the political economy of domestic work in Lebanon. E-International Relations. https://www.e-ir.info/pdf/72614. Accessed 24 Mar 2020.

Biehl, J. (2005). Vita: Life in a zone of abandonment. Berkeley: University of California Press.

Biehl, J., Good, B., \& Kleinman, A. (2007). Introduction: Rethinking subjectivity. In J. Biehl, B. Good, \& A. Kleinman (Eds.), Subjectivity: Ethnographic investigations (pp. 1-23). Berkeley: University of California Press.

Bornstein, E., \& Redfield, P. (Eds.). (2010). Forces of compassion: Humanitarianism between ethics and politics. Santa Fe: School for Advanced Research Press.

Boyden, J. (2003). Children under fire: Challenging assumptions about children's resilience. Children, Youth, and Environments, 13(1), 1-29.

Boyden, J. \& de Berry, J. (Eds.). (2004). Children and youth on the front line: Ethnography, armed conflict and displacement. New York and Oxford: Berghahn Books.

Brubaker, R. (2009). Ethnicity, race, and nationalism. Annual Review of Sociology, 35, 21-42.

Buckner, E., Spencer, D., \& Cha, J. (2018). Between policy and practice: The education of Syrian refugees in Lebanon. Journal of Refugee Studies, 31(4), $444-465$.

Butler, J. (1997). The psychic life of power: Theories in subjection. Stanford: Stanford University Press.

Campkin, B., \& Cox, R. (2012). Introduction: Materialities and metaphors of dirt and cleanliness. In B. B. Campkin \& R. Cox (Eds.), Dirt: New geographies of cleanliness and contamination (pp. 1-10). London: I.B. Tauris.

Chaaban, J., Salti, N., Ghattas, H., Irani, A., Ismail, T., \& Batlouni, L. (2016). Survey on the socioeconomic status of Palestine refugees in Lebanon 2015. American University of Beirut/ UNRWA. https://www. unrwa.org/sites/default/files/content/resources/survey_on_the_economic_status_of_palestine_refugees in_lebanon_2015.pdf. Accessed 25 Apr 2019.

Chalcraft, J. (2009). The invisible cage: Syrian migrant workers in Lebanon. Stanford: Stanford University Press.

Chatty, D., Crivello, G., \& Hunt, G. L. (2005). Theoretical and methodological challenges of studying refugee children in the Middle East and North Africa: Young Palestinian, Afghan and Sahrawi refugees. Journal of Refugee Studies, 18(4), 387-409.

Chatty, D. (2010a). Displacement and dispossession in the modern Middle East. Cambridge: Cambridge University Press.

Chatty, D. (2010b). Palestinian refugee youth: Agency and aspiration. Refugee Survey Quarterly, 28(2-3), 318-338.

Chatty, D., \& Mansour, N. (2011). Unlocking protracted displacement: An Iraqi case study. Refugee Survey Quarterly, 30(4), 50-83.

Chit, B. \& Nayel, M. A. (2013). Understanding racism against Syrian refugees in Lebanon. Civil Society Knowledge Centre \& Lebanon Support. https://civilsociety-centre.org/paper/understanding-racismagainst-syrian-refugees-lebanon. Accessed 22 Apr 2019.

Coates, T. (2015). Between the world and me. New York: Spiegel \& Grau.

Cresswell, T. (2005). Moral geographies. In D. Atkinson, P. Jackson, D. Sibley, \& N. Washboure (Eds.), Cultural geography: A critical dictionary of key concepts (pp. 128-134). London: I.B. Tauris.

Christophersen, M. \& Thorleifsson, C. (2013). Lebanese contradictory responses to Syrian refugees include stress, hospitality, resentment. Policy brief. Fafo and American University Beirut. https://scholarworks. aub.edu.lb/handle/10938/21193. Accessed 21 Apr 2019.

Doraï, M. K. (2010). From camp Dwelllers to urban refugees? Urbanization and marginalization of refugee camps in Lebanon. In M. A. Khalidi (Ed.), Manifestations of identity. The lived reality of Palestinian refugees in Lebanon (pp. 87-108). Institute for Palestine Studies and French Institute of the Middle East. 
Douglas, M. (1984 [1966]). Purity and danger: An analysis of concepts of pollution and taboo. London: Routledge.

Elshtain, J. B. (1996). Commentary: Political children. Childhood, 3(1), 11-28.

Fassin, D. (2011). Racialization: How to do races with bodies. In F. E. Mascia-Lees (Ed.), A companion to the anthropology of the body and embodiment (pp. 419-434). Chichester: Wiley-Blackwell.

Fassin, D. (2012). Humanitarian reason: A moral history of the present. Berkeley: University of California Press.

Fassin, D. \& Rechtman, R. (2009). The empire of trauma: An inquiry into the condition of victimhood. R. Gomme, trans. Princeton: Princeton University press.

Feldman, I. (2017). Humanitarian care and the ends of life: The politics of aging and dying in a Palestinian refugee camp. Cultural Anthropology, 32(1), 42-67.

Feldman, I. (2018). Life lived in relief: Humanitarian predicaments and Palestinian refugee politics. Berkeley: University of California Press.

Feldman, I., \& Ticktin, M. (Eds.). (2010). In the name of humanity: The government of threat and care. Durham: Duke University Press.

Fernando, C., \& Ferrari, M. (Eds.). (2013). Handbook of resilience in children of war. New York: Springer.

Fiddian-Qasmiyeh, E. (2014). Gender and forced migration. In E. Fiddian-Qasmiyeh, G. Loescher, K. Long, \& N. Sigona (Eds.), The Oxford handbook of refugee and forced migration studies (pp. 395-408). Oxford: Oxford University Press.

Fiddian-Qasmiyeh, E. (2016). Repressentations of displacement from the Middle East and North Africa. Public Culture, 28(3), 457-473.

Fields, K. E., \& Fields, B. J. (2012). Racecraft: The soul of inequality in American life. London: Verso.

Fontanari, E. (2019). Lives in transit: An ethnographic study of refugees' subjectivity across European Borders. London: Routledge.

Foucault, M. (1982). The subject and power. Critical Inquiry, 8(4), 777-795.

Gatrell, P. (2017). Refugees - what's wrong with history? Journal of Refugee Studies, 30(2), 170-189.

Gonzalez-Sobrina, B., \& Goss, D. R. (2019). Exploring the mechanisms of racialization beyond the blackwhite binary. Ethnic and Racial Studies, 42(4), 505-510.

Grbac, P. (2013). Civitas, polis, and urbs: Reimagining the refugee camp as the city. Refugee studies Centre, working paper series no. 96. https://www.rsc.ox.ac.uk/files/files-1/wp96-civitas-polis-urbs-2013.pdf. Accessed 21 Apr 2019.

Hage, G. (2016). État de siege: A dying domesticating colonialism? American Ethnologist, 43(1), 38-49.

Hanafi, S., \& Long, T. (2010). Governance, governmentalities, and the state of exception in the Palestinian refugee camps of Lebanon. Journal of Refugee Studies, 23(2), 134-159.

Hart, J. (2004). Beyond struggle and aid: children's identities in a Palestinian refugee camp in Jordan. In J. Boyden \& J. de Berry (Eds.) Children and youth on the front Line: Ethnography, armed conflict and displacement (pp. 167-186). New York and Oxford: Berghahn Books.

Hart, J. (Ed.). (2008). Years of conflict: Adolescence, political violence and displacement. Studies in forced migration 25. New York and Oxford: Berghahn Books.

Hart, J. (2014). Children and forced migration. In E. Fiddian-Qasmiyeh, G. Loescher, K. Long, \& N. Sigona (Eds.), The Oxford handbook of refugee and forced migration studies (pp. 383-394). Oxford: Oxford University Press.

Herzfeld, M. (1997). Cultural intimacy: Social poetics in the nation-state. New York: Routledge.

Holzer, E. (2015). The concerned women of Buduburam: Refugee activists and humanitarian dilemmas. Ithaca: Cornell University Press.

Hughes, E. (2015). An American Atra? Boundaries of diasporic nation-building amongst Assyrians and Chaldeans in the United States. PhD Dissertation: University of Edinburgh.

Human Rights Watch (2016). Education for Syrian refugee children: What donors and host countries should do. https://www.hrw.org/sites/default/files/supporting_resources/education_for_syrian_refugee_children_ what_donors_and_host_countries_should_do.pdf. Accessed 22 Apr 2019.

Hutchinson, M., \& Dorsett, P. (2012). What does the literature say about resilience in refugee people? Implications for practice. Journal of Social Inclusion, 3(2), 55-78.

James, A. \& Prout, J. (Eds.). (1997). Constructing and reconstructing childhood: contemporary issues in the sociological study of childhood. Abingdon, Oxon: Routledge

Janmyr, M. (2016). The legal status of Syrian refugees in Lebanon. Working paper 33. Issam fares Institute for Public Policy and International Affairs. American University of Beirut. http://www.aub.edu. lb/ifi/Documents/publications/working_papers/2015-2016/20160331_Maja_Janmyr.pdf. Accessed 23 Apr 2019. 
Janmyr, M., \& Mourad, L. (2018). Modes of ordering: Labelling, classification and categorization in Lebanon's refugee response. Journal of Refugee Studies, 31(4), 544-565.

Jureidini, R. (2002). Women migrant domestic workers in Lebanon. Geneva: International Labour Organisation. https://www.ilo.org/wcmsp5/groups/public/\%2D\%2D-ed_protect/\%2D\%2D-protrav/\%2 D\%2D-migrant/documents/publication/wcms_201777.pdf. Accessed 25 Mar 2020.

Jureidini, R., \& Moukarbel, N. (2004). Female Sri Lankan domestic workers in Lebanon: A case of "contract slavery'? Journal of Ethnic and Migration Studies, 30(4), 581-607.

Kihato, C. W. \& Landau, L. B. (2017). Stealth humanitarianism: Negotiating politics, Precarity and performance Management in Protecting the urban displaced. Journal of Refugee Studies, 30(3), 407-424).

Kovner, B., \& Shalhoub-Kevorkian, N. (2018). Children, human rights organisations, and the law under occupation: The case of Palestinian children in East Jerusalem. The International Journal of Human Rights, 22(5), 616-639.

Makdisi, S. (2006). Beirut, a city without history? In S. Makdisi \& P. Silverstein (Eds.), Memory and violence in the Middle East and North Africa (pp. 201-214). Bloomington: Indiana University Press.

Malkki, L. H. (1995). Refugees and exile: From 'refugee studies' to the national order of things. Annual Review of Anthropology, 24, 495-523.

Malkki, L. H. (1996). Speechless emissaries: Refugees, humanitarianism, and Dehistoricization. Cultural Anthropology, 11(3), 377-404.

Malkki, L. H. (2015). The need to help: The domestic arts of international humanitarianism. Durham: Duke University Press.

Marshall, D. J. (2013). 'All the beautiful things': Trauma, aesthetics and the politics of Palestinian childhood. Space and Polity, 17(1), 53-73.

Marshall, D. J. (2014). Save (us from) the children: Trauma, Palestinian childhood, and the production of governable subjects. Children's Geographies, 12(3), 281-296.

Martin, D. (2015). From spaces of exception to 'campscapes': Palestinian refugee camps and informal settlements in Beirut. Political Geography, 44, 9-18.

MEHE (2016). Reaching all children with education in Lebanon: RACE II (2017-2021). August 2016. Ministry of Education and higher education, Lebanon. http://race.mehe.gov.lb/wpcontent/uploads/RACE-II_FINAL-Narrative_29AUG2016.pdf. Accessed 23 Apr 2019.

Miles, R., \& Brown, M. (2003). Racism (2nd ed.). London: Routledge.

Moore, N. (2012). The politics and ethics of naming: Questioning anonymisation in (archival) research. International Journal of Social Research Methodology, 15(4), 331-340.

Murji, K., \& Solomos, J. (Eds.). (2005). Racialization: Studies in theory and practice. Oxford: Oxford University Press.

Nguyen-Gillham, V., Giacaman, R., Naser, G., \& Boyce, W. (2008). Normalising the abnormal: Palestinian youth and the contradictions of resilience in protracted conflict. Health and Social Care in the Community, 16(3), 291-298.

Oberprantacher, A., \& Siclodi, A. (Eds.). (2016). Subjectivation in political theory and contemporary practices. London: Palgrave Macmillan UK.

Omi, M., \& Winant, H. (2015). Racial formation in the United States (3rd ed.). New York: Routledge.

Owens, P. (2009). Reclaiming 'bare life'?: Against Agamben on refugees. International Relations, 23(4), 567-582.

Peteet, J. (1994). Male gender and rituals of resistance in the Palestinian "Intifada": A cultural politics of violence. American Ethnologist, 21(1), 31-49.

Pupuvac, V. (2008). Traumatic representations and political disenchantment. Government and Opposition, 43(2), 270-292.

Rajaram, P. K. (2002). Humanitarianism and representations of the refugee. Journal of RefugeeStudies, 15(3), 247-264.

Ramadan, A. (2013). Spatialising the refugee camp. Transactions of the Institute of British Geographers, $38(1), 65-77$.

Rancière, J. (1992). Politics, identification, and subjectivization. October, 61, 58-64.

Rancière, J. (1999). Disagreement: Politics and philosophy. J. Rose, trans. Minneapolis: University of Minnesota Press.

Rancière, J. (2004). Who is the subject of the rights of man? The South Atlantic Quarterly, 103(2/3), 297-310.

Rancière, J. (2016). Dissensus: On Politics and aesthetics. S. Corcoran, ed. and trans. London: Bloomsbury.

Riga, L., Holmes, M., Dakessian, A., Langer, J., \& Anderson, D. (forthcoming). Young refugees and forced displacement: Navigating everyday life in Beirut. Abingdon, Oxon: Routledge.

Rios, V. M. (2011). Punished: Policing the lives of black and Latino boys. New York: New York University Press. Salibi, K. S. (2003). A house of many mansions: The history of Lebanon reconsidered. London: I.B. Tauris. Seidman, S. (2012). The politics of cosmopolitan Beirut: From the stranger to the other. Theory, Culture \& Society, 29(2), 3-36. 
Sharif, H. (2018). Refugee-led humanitarianism in Lebanon's Shatila camp. Forced Migration Review, 57, 10-12. Shuayb, M., Makkouk, N., \& Tuttunji, S. (2014). Widening access to quality education for Syrian refugees: The role of private and NGO sectors in Lebanon (pp. 48-70). London and Beirut: Centre for Lebanese Studies. https://lebanesestudies.com/wp-content/uploads/2014/09/Widening-Access-to-QualityEducation-for-Syrian-Refugees-the-role-private-and-NGO-sectors-in-Lebanon-.pdf. Accessed 22 Apr 2019.

Sigona, N. (2014). The politics of refugee voices: Representations, narratives, and memories. In E. FiddianQasmiyeh, G. Loescher, K. Long, \& N. Sigona (Eds.), The Oxford handbook of refugee and forced migration studies (pp. 369-382). Oxford: Oxford University Press.

Sigona, N. (2015). Campzenship: Reimagining the camp as a social and political space. Citizenship Studies, $19(1), 1-15$.

Song, M. (2014). Challenging a culture of racial equivalence. British Journal of Sociology, 65(1), 107-129.

Taylor, C. (1989). Sources of the self: The making the modern identity. Cambridge: Cambridge University Press.

Thorleifsson, C. (2016). The limits of hospitality: Coping strategies among displaced Syrians in Lebanon. Third World Quarterly, 37(6), 1071-1082.

Ticktin, M. (2011). Casualties of care: Immigration and the politics of humanitarianism in France. Berkeley: University of California Press.

Traboulsi, F. (2012). A history of modern Lebanon (2nd ed.). London: Pluto Press.

UNHCR (2017). Resilience and self-reliance from a protections and solutions perspective. Executive Committee of the High Commissioner's Programme EC/68/SC/CRP.4. https:/www.unhcr. $\mathrm{org} / \mathrm{excom} / \mathrm{standcom} / 58 \mathrm{ca} 4 \mathrm{f} 827 /$ resilience-self-reliance-protection-solutions-perspective.html. Accessed 25 Apr 2019.

UNHCR \UNICEF\WFP (2017). Vulnerability Assessment of Syrian Refugees in Lebanon. https://www. unhcr.org/lb/wp-content/uploads/sites/16/2018/01/VASyR-2017.pdf. Accessed 23 Apr 2019.

UN (2019). Lebanon Crisis Response Plan 2017-2020 (2019 Update). United Nations and Government of Lebanon. https://data2.unhcr.org/en/documents/download/68651. Accessed 23 Apr 2019.

UNICEF/ Save the Children (2012). Education rapid needs assessment for displaced syrian children in schools, community and safe spaces. UNICEF Lebanon Country Office and Save the Children. https://data2.unhcr.org/en/documents/download/36499. Accessed 25 Apr 2019.

Wyness, M. (2015). Childhood. Cambridge,: Polity Press.

Zetter, R. (2007). More labels, fewer refugees: Remaking the refugee label in an era of globalization. Journal of Refugee Studies, 20(2), 172-192.

Publisher's note Springer Nature remains neutral with regard to jurisdictional claims in published maps and institutional affiliations.

Liliana Riga is Senior Lecturer in Sociology at the University of Edinburgh. She is a political and comparative historical sociologist focused on racism, nationalism and forced migration. Her first book, The Bolsheviks and the Russian Empire (Cambridge, 2012), was a comparative historical sociology of ethnicity, assimilation and political exclusion. Her current work examines nation-building, politicized racism and civil society during the Progressive Era's Americanization moment. She is lead author of a forthcoming book, Young Refugees and Forced Displacement: Navigating Everyday Life in Beirut (Routledge).

Johannes Langer is a $\mathrm{PhD}$ candidate in Sociology at the University of Edinburgh. His dissertation, "Leaning Right: A Comparative Sociology of Rightist Populism in the UK and Germany," comparatively explores the current rise of nationalism, focusing on regional difference and historical social change. His research interests involve racism, nationalism, immigration and forced displacement. He is a co-author of a forthcoming book, Young Refugees and Forced Displacement: Navigating Everyday Life in Beirut (Routledge).

Arek Dakessian is a Postdoctoral Research Fellow at the Institute for Global Health and Development in Queen Margaret University. He is a cultural sociologist working on forced displacement and integration in the UK. His doctoral dissertation, "Casting Nets and Framing Films: An Ethnography of Networks of Cultural Production in Beirut" explored material culture and social network analysis and cultural production. His current project revolves around the possibilities for dissensual politics in Beirut. He is a co-author of a forthcoming book, Young Refugees and Forced Displacement: Navigating Everyday Life in Beirut (Routledge). 


\section{Affiliations}

\section{Liliana Riga $^{1}$ • Johannes Langer ${ }^{1} \cdot$ Arek Dakessian $^{2}$}

1 Sociology, School of Social and Political Science, 6.24 CMB, University of Edinburgh, 15A George Square, Edinburgh EH8 9LD, UK

2 Institute for Global Health and Development, Queen Margaret University, Queen Margaret University Drive, Musselburgh EH21 6UU, UK 